\title{
Risk Değerlendirme Matris Yöntemi Kullanarak Okullarda Deprem Kaynaklı Yapısal Olmayan Risklerin Olası Etkilerinin Belirlenmesi
}

\author{
Hüseyin BAYRAKTAR¹, Elif SAHTIYYANCI² , Ali KURU³
}

\begin{abstract}
Özet
Ülkemizde okulların inşasında yapısal elemanlar ile ilgili yönetmelik, denetim ve kontroller yeterliliğe sahipken yapısal olmayan elemanlar ile ilgili yönetmelik, bilgi, uygulamalar vb yeterli değildir. Bu durum okullarda yapısal olmayan elemanların gelişigüzel alınmasına, olası bir afet etkisi düşünülmeden rastgele yerleştirilmeleri gibi daha birçok olumsuzluğa neden olmaktadır. Sonuçta okullarda yapısal olmayan elemanlardan kaynaklı risklere ve tehlikelere davetiye çıkarılmaktadır. Henüz okulların proje aşamasında yapısal elemanlarla birlikte yapısal olmayan elemanların değerlendirilmesi sonradan oluşabilecek riskleri ve dolayısıyla tehlikeleri ortadan kaldıracaktır. Bu çalışmada, okulların yapısal olmayan riskleri ve olası etkileri L Matris Yöntemi kullanılarak matematiksel ifadelere dönüştürülmüş ve her bir okulun risk puanı hesaplanmıștır. Son olarak üç okulun risk puanları birbirleriyle karşılaştırılarak risk seviyeleri belirlenmiştir. Çalışmanın amacı, örneklem olarak seçilen okullarda yerinde tespitler yaparak yapısal olmayan risklerin azaltılması ve risklerin ortadan kaldırılması için getirilen önerileri ilgili kurumlar ile paylaşmaktır.
\end{abstract}

Anahtar Kelimeler: Kaynaşl, Deprem, Risk, Okullarda Yapısal Olmayan Elemanlar, L Tipi Matris

\section{Determination of The Possible Effects of Non-Structural Risks Originating From Earthquake in Schools By Using Risk Assessment Matrix Method}

\begin{abstract}
Regulations, audits and controls related to structural systems in our country are adequate for the construction of schools, while regulations, information, practices etc. related to non-structural systems are not sufficient. This situation causes many other problems such as the randomization of non-structural elements in schools and the random placement of them without considering a possible disaster effect. As a result, in schools, risks and dangers arising from non-structural elements are invited. The evaluation of non-structural systems as well as structural systems at the project stage of the schools will eliminate the risks and consequently the dangers. In this study,
\end{abstract}

${ }^{1}$ Dr. Öğr. Üyesi, Yapı Ressamlı̆̆ Bölümü, Kaynaşlı MYO, Düzce Üniveristesi, Düzce İlgili yazar / Corresponding author: huseyinbayraktar@duzce.edu.tr

2 Öğr.Gör., Mimarlık ve Șehir Planlama Bölümü, Kaynaşlı MYO, Düzce Üniveristesi, Düzce

3 Öğr.Gör., Mülkiyet Koruma ve Güvenlik Bölümü, Kaynaşlı MYO, Düzce Üniveristesi, Düzce

Bu makaleye atıf yapmak için- To cite this article Bayraktar, H. Sahtiyancı, E. ve Kuru, A. (2019). Risk Değerlendirme Matris Yöntemi Kullanarak Okullarda Deprem Kaynaklı Yapısal Olmayan Risklerin Olası Etkilerinin Belirlenmesi. Afet ve Risk Dergisi, 2(2), 128-152. 
Afet ve Risk Dergisi Cilt: 2 Sayı: 2, 2019 (128-152)

non-structural risks and possible effects of schools were converted into mathematical expressions using the L Matrix Method and the risk score of each school was calculated. Finally, the risk scores of three schools were compared and risk levels were determined. The aim of the study is to share the proposals with the relevant institutions in order to reduce the non-structural risks and eliminate the risks by making on-site determinations in the schools selected as samples.

Keywords: Kaynaşl, Earthquake, Risk, Non-Structural Elements in Schools, L Type Matrix

\section{GíRis}

Depremler yer kürenin bir gerekliliği ve olağan hareketiyle geçmişten günümüze ola gelmiş bundan sonra da olmaya devam edecektir. Yapılması gereken depremin bir tehlike oluşturabileceği ve buna karşı neler yapılabileceğini bilmektedir. İnsanlar depremden korunmak için doğru planlamalar yaptıklarında zarar görmeden olağan yaşantılarına devam edebilirler. $\mathrm{Ne}$ yazık ki tarih boyunca bu böyle olmamış ve depremler bizim için hep birer yıkıcı afetler olarak karşımıza çıkmıştır. Depremin tehlikeye neden olmaması yani afete dönüşmemesi için bizim deprem olayına karşı bilinçli yaşamamız gerekmektedir. Bu bilincin bireyden topluma, özel kuruluşlardan kamu kurumlarına kadar deprem merkezli eğitim, yönetmelik, koordinasyonun sağlandığı bir temelde sürdürülmesi depremi afet değil bir olay olarak görmemizi ve konuşmamızı sağlayacaktır.

Ülkemizde meydana gelen deprem, heyelan, sel, yangın vb afet olayları çeşitlilik göstermekle birlikte bunlar arasında can ve ekonomik kayıp yönünden en büyük etkiyi depremler yapmaktadır. Son yaşanan depremler arasında 17 Ağustos 1999 Marmara Depremi ve 12 Kasım 1999 Düzce depremlerinin sonuçları ülkemiz açısından ağır olmuştur.

Depremler dolaylı olarak da olsa yaşama dair ne varsa etkileyebilmektedir. Depremler can ve ekonomik kayıplar yanında sosyal olarak da kayıplara neden olabilmektedir. 12 Kasım 1999 Düzce Depremi sadece can kayıpları değil sosyoekonomik bakımdan da yerleşim yerini olumsuz etkilemiştir (Ulusoy, R. 2000). 12 Kasım 1999 Düzce Depremi sonucunda Düzce'de toplam 763 can kaybı oluşmuş, 4948 kişi de yaralanmıștır. Konut hasarı bakımından baktığımızda ise 26.704 ağır hasarlı, 37.825 orta hasarlı ve 40.944 hafif hasarlı konut olduğu tespit edilmiștir (Özmen, B. 2000). Şekil 1'de Kuzey Anadolu Fay Hattı segmentine bağlı Düzce Fayı üzerinde 12 Kasım 1999 Düzce Depreminde meydana gelen yüzey kırı̆̆ görülmektedir. 17 Ağustos 1999 Marmara Depreminin tetiklemesiyle oluşan 12 Kasım 1999 Düzce Depreminde en çok etkilenen yer Kaynaşlı merkez olmuştur.

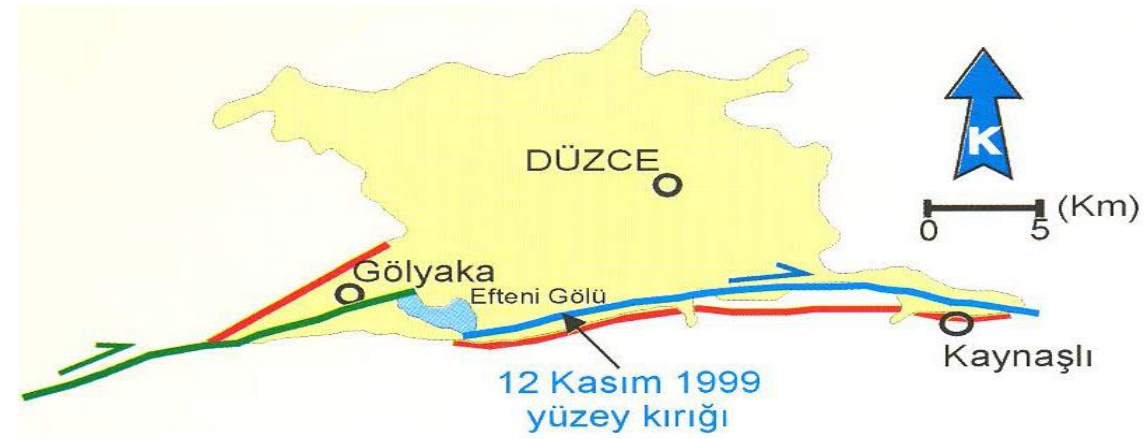

Şekil 1. Kuzey Anadolu Fay Hattının 17 Ağustos ve 12 Kasım 1999 depremleri yüzey kırı̆̆ı ile birlikte tek bir hat olarak davranmaya çalışması (Ulusoy, R. 2000) 
Risk Değerlendirme Matris Yöntemi Kullanarak Okullarda Deprem Kaynaklı Yapısal Olmayan Risklerin Olası Etkilerinin Belirlenmesi

\section{KAYNAŞLI VE 12 KASIM 1999 DÜZCE DEPREMİ}

\subsection{Kaynaşlı'da 12 Kasım 1999 Düzce Depreminin etkisi}

Kaynaşlı, 12 Kasım 1999 Düzce Depremi öncesi Bolu'nun bir ilçesi olan Düzce'ye bağlı bir Bucak'tır. Deprem sonrası 9 Aralık 1999 tarihinde Bakanlar Kurulu kararıyla Düzce'nin 81. İl olarak kabul edilmesinden sonra Kaynaşlı Düzce iline bağlı bir ilçe statüsüne kavuşmuştur. Kaynaşlı ilçesi 7 mahalle ve 20 köye sahip, Ankara-İstanbul illerine eşit mesafede, D-100 karayolu ve E5 otoyolu ana bağlantı yolları üzerindedir. İlçenin 2018 yılı toplam nüfusu 20.772'dir.

12 Kasım 1999 Düzce Depreminde en çok etkilenen yerlerden biri Kaynaşlı merkezdir. 40 km uzunluğundaki Düzce Fayının 6.5 km'lik kısmı Kaynaşlı merkezinden geçmiş ve özellikle 6.5 km uzunluğunda fay hattı üzerinde bulunan yapılarda yıkımlar, ağır hasarlar meydana gelmiștir. Kaynaşlı merkezinden geçen 6.5 km'lik fay kırığında $75 \mathrm{~cm}$ ile $3 \mathrm{~m}$ arasında ötelemeler oluşmuştur. Bu ötelemeler Kaynaşlı'da yapılar üzerinde büyük hasarlara neden olmuştur. 12 Kasım 1999 Düzce Depreminde Düzce Merkez'de 463 vefat, 1849 yaralı, Kaynaşlı'da 316 vefat, 543 kişi de yaralanmıştır. İlçe merkezinde altyapının tamamı hasar almış ve deprem sonrası hemen kullanılamamıştır. Konutların \%72'si ağır hasar, ticari işletmeler ve hizmet binalarının ise tümü yıkılmıştır (Acil Destek Vakfı arşivi, 1999).

\subsection{Kasım 1999 Düzce Depremi Öncesi ve Sonrası Kaynaşlı'da Okulların Durumları}

Kaynaşlı'nın deprem öncesi yapılan en eski okulu Kaynaşlı İlkokuludur. Kaynaşlı İlkokulu'nda ilk defa 1945 yllında eğitim-öğretime başlanmıştır. Daha sonra bu okul yerine 1965 yılında yeni bir okul yapılmış ve eğitim donanımlı yeni okulda devam etmiştir. Yeni binasında hizmet veren Kaynaşlı İlkokulu 1984 yılından sonra Kaynaşlı Lisesi olarak eğitime devam etmiştir. Fakat okul 12 Kasım 1999 Düzce depreminde yıkılmıştır.

Deprem sonrasında Kaynaşlı merkezde bulunan okulların yıkılması nedeni ile eğitim-öğretim üç hafta kadar durmuş, hemen sonrasında eğitim-öğretime geçilmiştir. Köylerdeki okullarda pek hasar bulunmamaktadır. Merkezde ise Kaynaşlı İlköğretim Okulu ve Kaynaşlı Lisesi yıkılmıștır. Süperlit İlköğretim Okulu ve Dariyeri Hasanbey İlköğretim Okulu orta hasar aldıklarından deprem sonrası hemen kullanılamamıştır. Deprem sonrası Kaynaşlı, deprem bölgesinde okullarda eğitimöğretime başlayan ilk merkez olmuştur. 2000 tarihinde Kaynaşlı'da 2425 ilköğretim öğrencisi ve 150 lise öğrencisi 108 öğretmen eşliğinde, ilk olarak çadır sınıflarda, daha sonra prefabriklerde örgün eğitime devam etmiștir. 2002 yılından itibaren eğitim-öğretim yeni yapılan okul binalarında sürdürülmüştür Kaynaşlı Kriz Yönetim Merkezi arşivi (1999-2001 arası kayıtlı bilgiler).

Günümüzde Kaynaşlı'da içerisinde anaokulu, ilkokul, ortaokul ve lise olmak üzere toplam 19 okul bulunmaktadır. Bu okullardan merkezde yer alanlardan sadece Karaçalı Süperlit İlkokulu deprem öncesi yapılmış okul olup depremde orta hasar almıștır. Karaçalı Süperlit İlkokulu deprem sonrasında Kaynaşlı'da faaliyet gösteren Süperlit A.Ş. tarafından onarım projesi yaptırılarak onarım görmüş ve tekrar kullanımı sağlanmıştır. Halen Karaçalı Süperlit İlkokulu'nda eğitimöğretim devam etmektedir.

\section{YAPISAL OLMAYAN ELEMANLAR}

Binaların yapısal elemanları yani taşıyıcı sistemleri (kolon, kiriş, döşeme, çatı vb) dışında kalan tüm eşya ve türevleri yapısal olmayan elemanlardır. Yapısal olmayan elemanlar yaşadığımız okul, hastane, ev, kütüphane, işyeri vb neredeyse tüm ortamlarda risk oluşturabilmektedir. Risklerin azaltılmasında eşyaların yerlerini değiştirmek, sabitlemek gibi farklı basit ya da karmaşık 
Afet ve Risk Dergisi Cilt: 2 Sayı: 2, 2019 (128-152)

Hüseyin BAYRAKTAR, Elif SAHTIYANCI, Ali KURU önlemler alınabilmektedir (Durukal, vd 2008). Depremlerde binalar sadece yapısal olarak zarara uğramamaktadır. Aynı zamanda yapısal olmayan elemanların meydana getirdiği zararlarda oluşabilmektedir. 17 Ağustos 1999 Marmara Depreminde kayıpların \%3'ü, yaralanmaların ise \%50'sinin yapısal olmayan elemanlardan kaynaklandığı tespit edilmiștir (AHEB, 2004). Yapısal olmayan elemanlara karşı alınacak önlemlerde yönetmelikler de belirleyici ve yönlendirici olacaktır. Taşıyıcı sistem dışında oluşabilecek risklere karşı neler yapılması gerektiği yönetmeliklerle sabit kılınması ve özellikle kamuya açık yerlerde (okul, hastane, kütüphane, müze vb) yapısal olmayan önlemlerin alınmadığı durumlarda kanuni yaptırımların yer alması risklerin azalmasını sağlayabilecektir (Bayraktar, H. 2015).

Yapısal olmayan elemanların deprem anında gösterebilecekleri reaksiyonlar deneysel çalışmalarla belirlenerek optimizasyonun sağlanması ve bu doğrultuda standartların geliştirilerek yönetmeliklerle işlevsel hale getirilmesi yapısal olmayan tehlikeleri önleyebilecektir (İpek, vd. 2015).

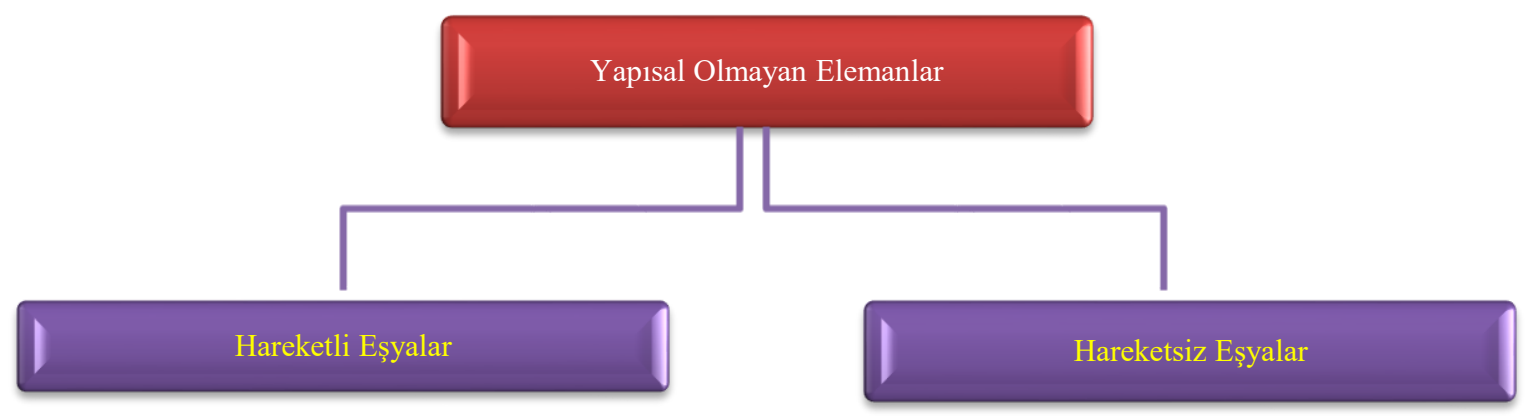

Şekil 2. Yapısal olmayan elemanların hareketli ve hareketsiz eşyalar olarak ayrılması

Hareketli eșyalar; dolap, sehpa, beyaz eșyalar (buzdolabı, firın, bulașık makinesi vb), bilgisayar, vazo, çerçeveli resim panosu, kitaplık rafları, sıra, sandalye, tekerlekli eşyalar gibi herhangi bir dış kuvvete maruz kaldıklarında gelen etkinin büyüklüğüne göre yer değiştiren elemanlardır. Hareketli esyaların olası bir dıs kuvvete maruz kaldıklarında devrilmeyecek șekilde sabitlenmeleri önemlidir. Hareketsiz eșyalar ise çatı kaplaması, bacalar, bölme duvarlar, asma tavanlar, tesisat (yangın,elektrik, su, ısıtma, havalandırma, aydınlatma vb) sistemleri, kapı, pencere, iç ve dıș kaplamalar, sabit dekoratif elemanlar vb eșyalardır (Şekil 2).

\section{RİSK DEĞERLENDİRME MATRIS YÖNTEMİ}

AFAD Açıklamalı Afet Terimleri Sözlüğüne göre; Risk, bir olayın belirli koşul ve ortamlarda doğurabileceği can, mal, ekonomik ve çevresel gibi değerlerin kaybının gerçekleşme olasılığıdır. Tehlike ise doğa, teknoloji veya insan kaynaklı olan ve fiziksel, ekonomik, sosyal kayıplara yol açabilecek tüm olayları ifade etmektedir. Riskin neden olabileceği kayıpların gerçekleşme olasılığını değerlendirilerek önceden önlem alınması kayıplara yol açabilecek tehlikenin de ortadan kaldırılmasını sağlayabilecektir.

Amerika Birleşik Devletleri Savunma Bakanlığı tarafından 2000 yılında çıkarılan MIL_STD_882D standardında askeriyenin standart uygulamaları kapsamında sistem güvenliğinin kontrolden geçirilerek "sıfır kaza" hedefini gerçekleştirmek amacıyla "risk değerlendirme matris yöntemi" geliştirilmiştir. MIL_STD_882D standardından sonra ABD Savunma Bakanlığının tüm Askeri Birimler ve Savunma Ajansları tarafından kullanılması için 2012 yılında çıkarılan MIL_STD_882E güvenlik standardı uygulaması tehlikenin tanımlanmasını, sınıflandırılmasını ve azaltılması için 
Risk Değerlendirme Matris Yöntemi Kullanarak Okullarda Deprem Kaynaklı Yapısal Olmayan Risklerin Olası Etkilerinin Belirlenmesi

genel bir bakış açısıyla "risk değerlendirme matris yöntemi" daha da geliştirilmiştir. Yöntemde, risk değerlendirmesinin yapıldığı alanda elemanların zarar potansiyel seviyeleri; şiddet kategorileri (Tablo 1) ve olasılık seviyeleri (Tablo 2) olarak iki ayrı tabloda tanımlanmaktadır.

Kontrol edilen birden fazla elemana ait Şiddet kategorileri (Tablo 1) ve Olasılık seviyeleri (Tablo 2) bir tabloda karşılaştırılarak risk seviyelerinin sınıflandırıldığı risk değerlendirme matris tablosu elde edilmektedir (Tablo 3). İncelenen elemanın zarara yönelik olasılığı ve etkileme kabiliyeti (şiddet) arasında ilişki kurularak tablo 3'de yüksek, ciddi, orta, düşük veya elenmiş risk seviyeleri belirlenmektedir.

Tablo 1. Şiddet kategorileri

\begin{tabular}{|c|c|c|}
\hline \multicolumn{3}{|r|}{ Ş่DDDET KATEGORILERİ } \\
\hline Tanım & $\begin{array}{c}\text { Şiddet } \\
\text { Kategorisi } \\
\end{array}$ & Tehlike Sonuç Kriterleri \\
\hline Felaket & 1 & $\begin{array}{l}\text { Aşağıdakilerden biri veya birkaçıyla sonuçlanabilir: } \\
\text { Ölüm, kalıcı toplam sakatlık, geri dönüşü olmayan önemli çevresel etki veya } \\
10 \text { milyon ABD Dolarına eșit veya bu tutarı așan parasal kayıp. }\end{array}$ \\
\hline Kritik & 2 & $\begin{array}{l}\text { Aşağıdakilerden biri veya birkaçı ile sonuçlanabilir: } \\
\text { En az üç personelin hastaneye yatması, geri dönüşlü önemli çevresel etki veya } \\
10 \text { milyon ABD Dolarından az veya bu parayı aşan parasal kayıplarla } \\
\text { sonuçlanabilecek kalıcı kısmi sakatlık, yaralanmalar veya mesleki hastalıklar. }\end{array}$ \\
\hline $\begin{array}{l}\text { Önemi } \\
\text { Az olan }\end{array}$ & 3 & $\begin{array}{l}\text { Aşağıdakilerden biri veya birkaçıyla sonuçlanabilir: } \\
\text { Bir veya daha fazla kayıp iş günü / günleri, geri dönüşümlü ılımlı çevresel etki } \\
\text { veya } 100 \text { milyon ABD Doları'na eşit veya daha az } 1 \text { milyon ABD Dolarını aşan } \\
\text { parasal kayıplarla sonuçlanan yaralanma veya meslek hastalığı. }\end{array}$ \\
\hline Önemsiz & 4 & $\begin{array}{l}\text { Așağıdakilerden biri veya birkaçıyla sonuçlanabilir: } \\
\text { İş günü kaybı, minimum çevresel etki veya } 100.000 \text { Dolar'ın altındaki parasal } \\
\text { kayıplarla sonuçlanmayan yaralanma veya meslek hastalıkları. }\end{array}$ \\
\hline
\end{tabular}

Tablo 2. Olasılık seviyeleri

\begin{tabular}{|c|c|c|c|}
\hline \multicolumn{4}{|c|}{ OLASILIK SEVIYELERİ } \\
\hline Tanım & Seviye & Özel münferit madde & Filo veya sayım \\
\hline Sık Görülen & A & $\begin{array}{l}\text { Maddenin kullanımı boyunca sıklıkla meydana } \\
\text { gelme olasılığ }\end{array}$ & Sürekli deneyimli \\
\hline Muhtemel & B & $\begin{array}{l}\text { Maddenin kullanımı boyunca birkaç kez ortaya } \\
\text { çlkma olasılığı }\end{array}$ & Sıklıkla oluşabilecek \\
\hline Ara sira & $\mathrm{C}$ & $\begin{array}{llll}\begin{array}{l}\text { Maddenin kullanımı } \\
\text { gerçekleșmesi ihtimali }\end{array} & \text { boyunca } & \text { bazen } \\
\end{array}$ & $\begin{array}{lll}\text { Birkaç kez } & \text { ortaya } \\
\text { Çlkabilecek } & \end{array}$ \\
\hline Pek az & D & $\begin{array}{l}\text { Maddenin kullanımı boyunca düşük bir olasılıkla } \\
\text { gerçekleşmesi ihtimali }\end{array}$ & $\begin{array}{l}\text { Olası değil, makul bir } \\
\text { șekilde gerçekleșebilir }\end{array}$ \\
\hline $\begin{array}{l}\text { Muhtemel } \\
\text { Değil }\end{array}$ & E & $\begin{array}{l}\text { Maddenin kullanımı boyunca olası bir durumun } \\
\text { yașanmayabileceği ihtimali }\end{array}$ & $\begin{array}{llll}\text { Olması } & \text { olası değil ama } \\
\text { olabilir }\end{array}$ \\
\hline Elenmiş & $\mathrm{F}$ & $\begin{array}{l}\text { Oluşması elverişsiz. } \mathrm{Bu} \text { seviye, potansiyel } \\
\text { tehlikeler belirlendiğinde ve daha sonra ortadan } \\
\text { kaldırıldığında kullanılır }\end{array}$ & $\begin{array}{l}\text { Oluşması elverişsiz. } \mathrm{Bu} \\
\text { seviye, potansiyel tehlikeler } \\
\text { belirlendiğinde ve daha } \\
\text { sonra ortadan } \\
\text { kaldırıldığında kullanılır }\end{array}$ \\
\hline
\end{tabular}


Tablo 3. Risk değerlendirme matrisi

\begin{tabular}{|c|c|c|c|c|}
\hline \multicolumn{5}{|c|}{ RISSK DEĞERLENDİRME MATRİSI } \\
\hline OLASILIK & $\begin{array}{c}\text { Felaket } \\
\text { (1) }\end{array}$ & $\begin{array}{l}\text { Kritik } \\
(2)\end{array}$ & $\begin{array}{c}\text { Önemi az olan } \\
\text { (3) }\end{array}$ & $\begin{array}{c}\text { Önemsiz } \\
\text { (4) }\end{array}$ \\
\hline $\begin{array}{l}\text { Sik Görülen } \\
\text { (A) }\end{array}$ & Yüksek & Yüksek & Ciddi & Orta \\
\hline $\begin{array}{l}\text { Muhtemel } \\
\text { (B) }\end{array}$ & Yüksek & Yüksek & Ciddi & Orta \\
\hline $\begin{array}{l}\text { Ara Sira } \\
\text { (C) }\end{array}$ & Yüksek & Ciddi & Orta & Düşük \\
\hline $\begin{array}{l}\text { Pek Az } \\
\text { (D) }\end{array}$ & Ciddi & Orta & Orta & Düşük \\
\hline $\begin{array}{l}\text { Muhtemel Değil } \\
\text { (E) }\end{array}$ & Orta & Orta & Orta & Düşük \\
\hline $\begin{array}{l}\text { Elenmiş } \\
\text { (F) }\end{array}$ & & & & \\
\hline
\end{tabular}

\subsection{Tipi Matris Yöntemi}

Risk değerlendirme karar matris metodolojilerinden L Tipi Matris yöntemi (5x5 matris diyagramı), ilişki kurulan değerlendirmeler arasında sebep kaynağı ve göstereceği sonuç arasında bağlantıyı ifadelendirmeyi sağlayan bir yöntemdir (Özkılıç, 2005). İncelenen alanda gördüğümüz herhangi bir olayın oluşma ihtimali ve bu ihtimalin olması durumunda meydana getirebileceği şiddetin çarpılmasıyla risk değerine ulaşılmaktadır.

L Tipi Matris yöntemi farklı çalışma alanlarında risk değerlendirmesi amacıyla kullanılabilmektedir. Örneğin (Soykan, 2018) endüstriyel balıkçı gemilerinde, (Koltan, vd 2010) işçi sağlığının uygunluğunun değerlendirilmesinde, (Tantoğlu, 2016) balıkçı gemilerinde iş sağlığı ve güvenliğinin değerlendirilmesinde, (Çeliktaş ve Ünlü, 2018) bilişim sistemleri alanında L Tipi Matris yöntemini kullanarak risk değerlendirmesi yapmışlardır. L Tipi Matris yöntemi ile yapılan risk değerlendirmeleri tehlikenin ve boyutunun belirlenmesinde, tehlikeye karşı gerçekleştirilecek eylemlerde yönlendirici bir yöntem olarak fayda sağlamaktadır.

Alanında uzman kişilerce birimlerde yapılan kontrol sonucunda risk değerini elde edebilmek için olasılık seviyesi ve etki kategorisi arasında çarpısal bir ilişki kurulmaktadır. "Risk değeri = Etki $\mathrm{x}$ Olasıllk" formülüyle ifade edilmektedir (Tablo 4).

Risk değeri, etki ile olasılığın çarpılması ile riskin oluşturabileceği sonuç "çok düşük, düşük, orta, yüksek ya da çok yüksek" olabilmektedir. Bulunan risk değeri çok düşük ise "önemsiz riskler", düşük ise "katlanılabilir riskler", orta ise "orta düzeydeki riskler", yüksek ise "önemli riskler", çok yüksek ise "katlanılamaz riskler" sınıfına girmektedir. Olasılık ve etki (şiddet) çarpımı ile elde edilen risk değeri sonuç aralığına göre hangi eylemin yapılması gerektiği belirlenmektedir (Tablo $5)$. 
Risk Değerlendirme Matris Yöntemi Kullanarak Okullarda Deprem Kaynaklı Yapısal Olmayan Risklerin Olası Etkilerinin Belirlenmesi

Tablo 4. Risk değerinin elde edilmesinde kullanılan etki ve olasılık ölçütleri (Özkılıç, 2005)

\begin{tabular}{|c|c|c|c|c|c|c|}
\hline \multirow{2}{*}{\multicolumn{2}{|c|}{$\begin{array}{l}\text { RİSK= ETKİ X } \\
\text { OLASILIK }\end{array}$}} & \multicolumn{5}{|c|}{ ETKİ (ŞIDDDT) } \\
\hline & & $\begin{array}{c}\text { ÇOK AZ } \\
\text { ZARAR (1) }\end{array}$ & $\begin{array}{l}\text { ÖNEMSİZ } \\
\text { ZARAR } \\
(2)\end{array}$ & $\begin{array}{l}\text { ORTA } \\
\text { ZARAR } \\
\text { (3) }\end{array}$ & $\begin{array}{l}\text { CİDDİ ZARAR } \\
\text { (4) }\end{array}$ & $\begin{array}{l}\text { ÇOK CİDDİ } \\
\text { ZARAR } \\
\text { (5) }\end{array}$ \\
\hline \multirow{5}{*}{ 当 } & $\begin{array}{c}\text { ÇOK AZ } \\
\text { İHTİMALLE (1) }\end{array}$ & $\begin{array}{c}\text { Çok } \\
\text { Düşük(1) }\end{array}$ & Düşük(2) & Düşük(3) & Düşük (4) & Düşük (5) \\
\hline & $\begin{array}{l}\text { AZ İHTİMALLE } \\
\text { (2) }\end{array}$ & Düşük(2) & Düşük (4) & Düșük (6) & Orta (8) & Orta (10) \\
\hline & $\begin{array}{c}\text { ORTA } \\
\text { İHTİMALLE (3) }\end{array}$ & Düşük(3) & Düşük (6) & Orta (9) & Orta (12) & Yüksek (15) \\
\hline & $\begin{array}{c}\text { BÜYÜK } \\
\text { İHTİMALLE (4) }\end{array}$ & Düşük(4) & $\operatorname{Orta}(8)$ & Orta (12) & Yüksek (16) & $\begin{array}{c}\text { Çok } \\
\text { Yüksek(20) }\end{array}$ \\
\hline & KESİNLİKLE (5) & Düşük (5) & Orta (10) & Yüksek(15) & $\begin{array}{c}\text { Çok } \\
\text { Yüksek(20) }\end{array}$ & $\begin{array}{c}\text { Çok } \\
\text { Yüksek(25) }\end{array}$ \\
\hline
\end{tabular}

Tablo 5. Risk değeri puan aralığına göre sonuç ve sonuca yönelik eylem adımları (Özkılıç, 2005)

\begin{tabular}{|c|c|c|}
\hline : & SONUÇ & EYLEM \\
\hline 论绻 & $\begin{array}{l}\text { KATLANILAMAZ RİSKLER } \\
(20-25)\end{array}$ & $\begin{array}{l}\text { Belirlenen risk kabul edilebilir bir seviyeye } \\
\text { düşürülünceye kadar iş başlatılmamalı, eğer } \\
\text { devam eden bir faaliyet varsa derhal } \\
\text { durdurulmalıdır. Gerçekleştirilen faaliyetlere } \\
\text { rağmen riski düşürmek mümkün olmuyorsa, } \\
\text { faaliyet engellenmelidir. }\end{array}$ \\
\hline 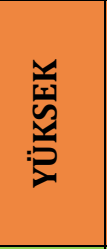 & $\begin{array}{l}\text { ÖNEMLİ RISSKLER } \\
\mathbf{( 1 5 - 1 6 )}\end{array}$ & $\begin{array}{l}\text { Belirlenen risk azaltılıncaya kadar iş } \\
\text { başlatılmamalı eğer devam eden bir faaliyet } \\
\text { varsa derhal durdurulmalıdır. Risk işin devam } \\
\text { etmesi ile ilgiliyse acil önlem alınmalı ve bu } \\
\text { önlemler sonucunda faaliyetin devamına karar } \\
\text { verilmelidir. }\end{array}$ \\
\hline$\stackrel{1}{a} \varangle$ & $\begin{array}{l}\text { ORTA DÜZEYDEKİ RİSKLER } \\
(8,9,10,12)\end{array}$ & $\begin{array}{l}\text { Belirlenen riskleri düşürmek için faaliyetler } \\
\text { başlatılmalıdır. Risk azaltma önlemleri zaman } \\
\text { alabilir. }\end{array}$ \\
\hline : & $\begin{array}{l}\text { KATLANILABİLİR RİSKLER } \\
(2,3,4,5,6)\end{array}$ & $\begin{array}{l}\text { Belirlenen riskleri ortadan kaldırmak için ilave } \\
\text { kontrol tedbirlerine ihtiyaç olmayabilir. Ancak } \\
\text { mevcut kontroller sürdürülmeli ve bu } \\
\text { kontrollerin sürdürüldüğü denetlenmelidir. }\end{array}$ \\
\hline 参: & $\begin{array}{l}\text { ÖNEMSİZ RİSKLER } \\
\text { (1) }\end{array}$ & $\begin{array}{l}\text { Belirlenen riskleri ortadan kaldırmak için } \\
\text { kontrol tedbirleri planlamaya ve } \\
\text { gerçekleştirilecek faaliyetlerin kayıtlarını } \\
\text { saklamaya gerek olmayabilir. }\end{array}$ \\
\hline
\end{tabular}




\section{5. ÇALIŞMA YÖNTEMİ}

Kaynaşlı İlçe Milli Eğitim Müdürlügüne bağlı 1'i anaokulu, 8'i ilkokul, 7'si ortaokul ve 3'ü lise olmak üzere toplam 19 okul bulunmaktadır. 2019 yılı Öğrenci sayılarına baktığımızda, Anaokulunda 266, İlkokullarda 1004, Ortaokullarda 1114 ve Liselerde 639 öğrenci olmak üzere tüm okullarda toplam 3023 öğrenci vardır. Bu okullarda çalışan toplam öğretmen sayısı ise 215'dir (Kaynaşlı İlçe Milli Eğitim Müdürlüğü).

Deprem bakımından kritik bir bölgede yer alan Kaynaşlı'da bu kadar çok öğrencinin bulunması okullarda afete yönelik çalışmaların önemini artırmaktadır. İlçede okulların biri hariç diğerleri deprem sonrası yapılmıştır. Deprem öncesi yapılan Karaçalı Süperlit İlkokulunda onarım çalışması yapılmıştır. Deprem sonrası yapılan yapılar ise yeni yönetmeliklere ve denetimlere göre yapıldığından yapısal olarak emniyet faktörü yüksektir. Deprem öncesi yapılan Karaçalı Süperlit İlkokulunda gerçekleştirilen onarımlar sayesinde okulun yapısal olarak emniyetli olduğu söylenebilir. Fakat okulların tümünde yapısal olmayan elemanlara yönelik yeterli çalışmaların yapılmadığı bilinmektedir. Çalışmamızda Kaynaşlı merkezde örneklem olarak seçilen 3 okulda yapısal olmayan elemanlara yönelik risk değerlendirmeleri yapılmıştır.

Örneklem olarak belirlenen üç okul için yapılacak çalışma öncesi Kaynaşlı İlçe Milli Eğitim Müdürlügünden yazışma yoluyla gerekli izinler alınmıștır. İzinler sonrasında Kaynaşlı merkezde bulunan okullar arasında en fazla öğrenci sayısına sahip biri ilkokul, biri ortaokul ve diğeri lise olmak üzere seçilen 3 okul (Kaynaşlı Anadolu Lisesi, Kaynaşlı Anadolu Kalkınma Vakfı Ortaokulu ve Kaynaşlı İlkokulu) için çalışma grupları oluşturulmuştur. Çalışma gruplarıyla yapılan toplantılarda izlenecek yol ve yöntem değerlendirilmiştir (Şekil 3). Okullarda yapısal olmayan risklerin tespiti okul bahçesi, okul girişi, koridorlar, derslikler, idari kısımlar vb anketler yoluyla (kontrol listeleri) yerinde incelemeler yapılarak belirlenmiştir. Riskli olarak değerlendirilen yapısal olmayan elemanların fotoğrafları çekilerek arşivlenmiştir. Çalışma sonucunda okullar hakkında elde edilen veriler L Matrisi yöntemi kullanılarak sayısal verilere dönüștürülmüştür. Değerlendirilen okulların yapısal olmayan elemanlar bakımından olası tehlikeleri oransal olarak belirlenmiş ve okullar risk bakımından birbirleri ile karş̧laştırılarak mevcut durum görünürlülüğü sağlanmıştır. Okullarla ilgili elde edilen sonuçlar Kaynaşlı İlçe Milli Eğitim Müdürlüğü ve ilgili okullar ile paylaşılmıştır. Şekil 3'de çalışmada izlenen yol sırasıyla açıklamalı olarak verilmektedir.

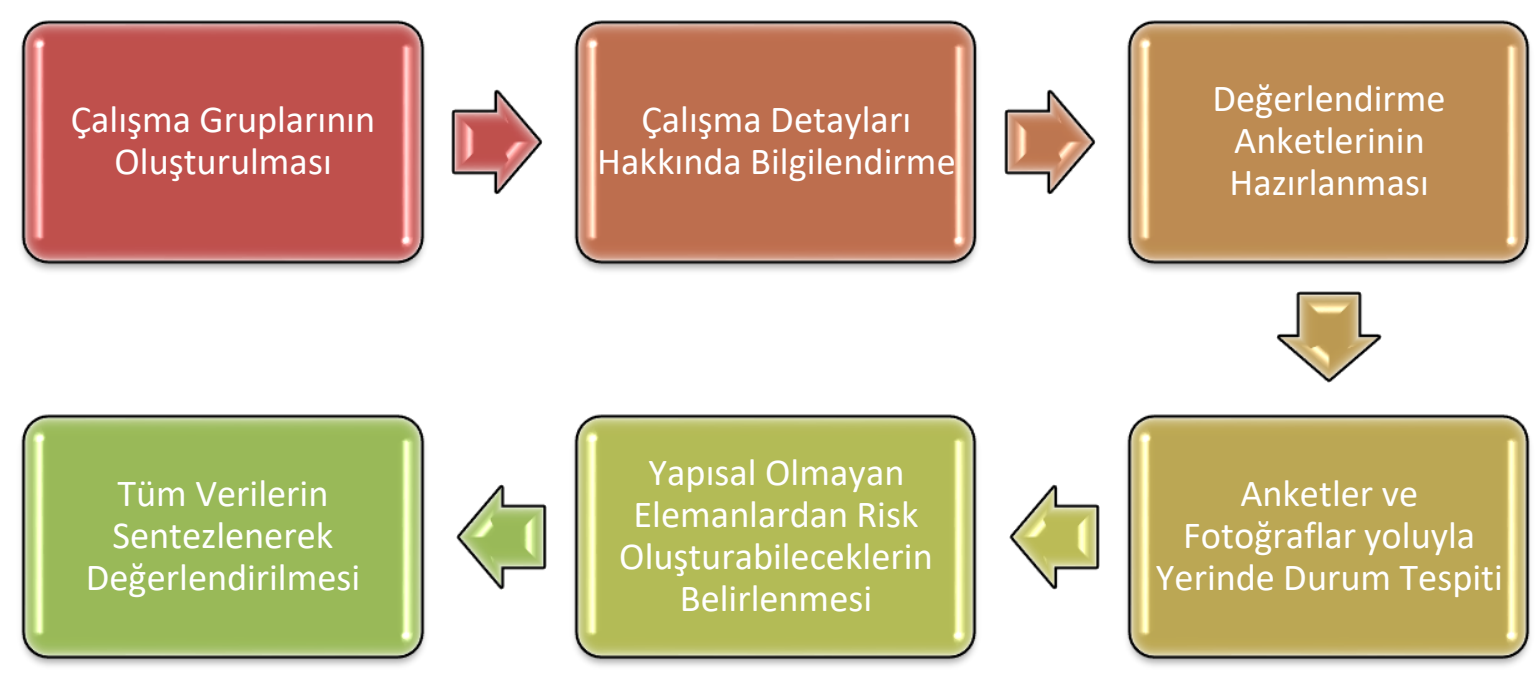

Şekil 3. Okullarda Yapısal Olmayan Risklerin Tespitinde İzlenen Yol 
Risk Değerlendirme Matris Yöntemi Kullanarak Okullarda Deprem Kaynaklı Yapısal Olmayan Risklerin Olası Etkilerinin Belirlenmesi

\section{TARTIŞMA VE BULGULAR}

Bu bölümde Kaynaşlı İlçe Milli Eğitim Müdürlüğüne bağlı örneklem olarak seçilen üç okula ait bulgular tartışılacaktır. İlk olarak Kaynaşlı Anadolu Lisesi, ikinci olarak Kaynaşlı Anadolu Kalkınma Vakfı Ortaokulu ve son olarak Kaynaşlı İlkokulu risk değerlendirmeleri ele alınacaktır. Okulların üçüne de 24 soruluk aynı kontrol listeleri (anketler) uygulanmıştır. Yerinde incelenerek tehlike analizi yapılan üç okula ait risk seviyeleri ve etkileri karşılaştırılacaktır. Böylece hangi okulun daha fazla ya da daha az yapısal olmayan elemanlar bakımından riske maruz kalabileceği görülebilecektir. Çalışmamızda okullar için bulunan "çok yüksek" ve "yüksek" risk seviyeleri birlikte ele alınarak okulların risk değerlendirilmesi yapılmış ve bu seviyelere daha fazla önem verilmesi üzerinde durulmuştur.

\subsection{Kaynaşlı Anadolu Lisesi}

İncelenen okul betonarme yapı olup, bodrum artı 3 kattan oluşmaktadır (Şekil 4). Okulda 24 öğretmen, 294 öğrenci bulunmaktadır. Okul binası 2006 yılında tamamlanarak eğitim-öğretime bașlanmıștır. Toplam kullanım alanı $3400 \mathrm{~m} 2$ olan okulda her katta kız/erkek olmak üzere 8 adet tuvalet, sığınak, kullanılmayan kazan dairesi, yemekhane, depolar, 18 derslik, 5 idari birim, 2 laboratuvar, kütüphane ve bilgisayar odası bulunmaktadır.

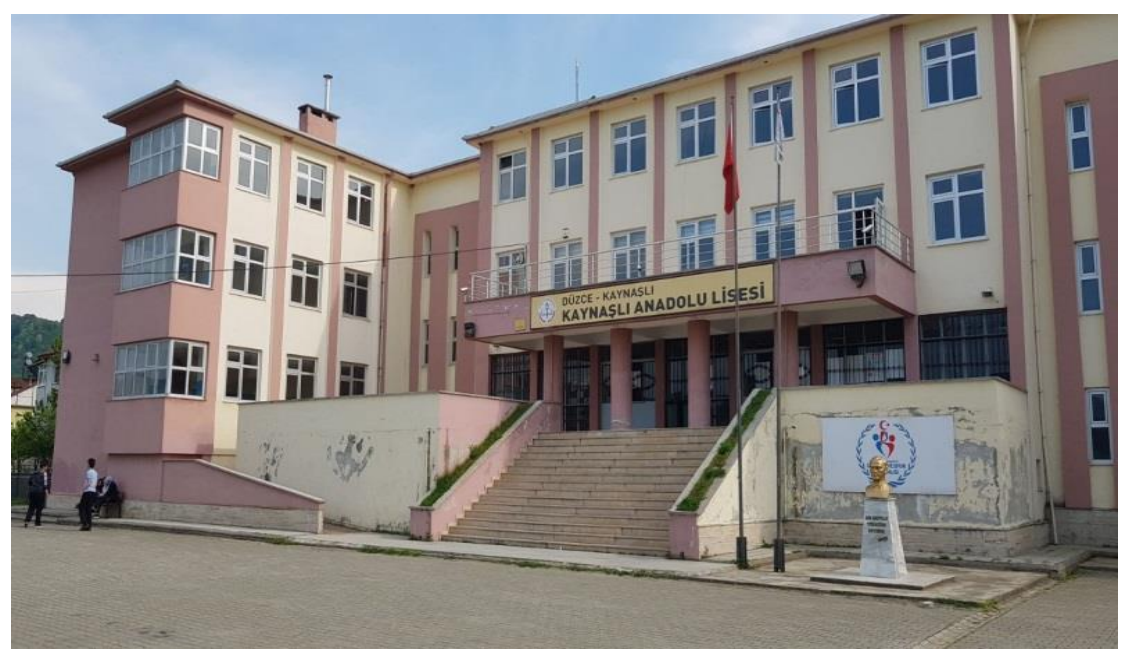

Şekil 4. Kaynaşlı Anadolu Lisesi okulun giriş kısmı

\subsubsection{Kaynaşlı Anadolu Lisesi'nde Yapılan Çalışmalar}

Çalışma grubuyla önceden hazırlanan toplam 24 soruluk kontrol listesi (anket) yoluyla okulun dıș alanından iç alanlarına risk oluşturabilecek özellikler tespit edilmiştir. Tespit edilen risklerin oluşma ihtimalleri ve etkileri kontrol listesinde gösterilmiştir (Tablo 6). Her bir maddenin risk değerinin bulunmasında tehlikenin oluşma ihtimali ve etkisi birbiriyle çarpılmıștır. Böylece 24 maddenin risk değeri, risk değerlendirme matris tablolarına (Tablo 4 ve Tablo 5) göre sınıflandırılmıştır. Tablo 4'de 1'den 5'e kadar olma ihtimali derecelendirilmektedir. Tablo 5'de ise risk seviyelerinin puan aralıkları yer almaktadır. "Risk değeri = Etki x Olasılık" formülü kullanılarak puanlamalar yapılmaktadır. Örneğin Tablo 6'da 1. Maddenin olma ihtimali 1'den 5'e kadar değerlendirildiğinde "1", 1'den 5'e kadar etkinin değerlendirilmesinde "4" ve Risk değeri = $1 \mathrm{x} 4$ ise risk değeri 4 puan olarak bulunmaktadır. Bu şekilde tüm okulların risk değerinin bulunmasında "etki x olasılık" formülünün sonucuna göre belirlenmektedir. Tablo 5'de yer alan puanlama karşılık yapılması gereken eylem maddesi bulunabilmektedir. 
Tablo 6. Kontrol listeleri (anket çalışması)

\begin{tabular}{|c|c|c|c|c|c|}
\hline \multicolumn{6}{|c|}{ OKUL ADI: KAYNAŞLI ANADOLU LİSESİ ANKET ÇALIŞMASI } \\
\hline & No & Risk & $\begin{array}{c}\text { Olma } \\
\text { İhtimali }\end{array}$ & Etki & $\begin{array}{c}\text { Risk } \\
\text { Değeri }\end{array}$ \\
\hline \multirow{2}{*}{ 宓 } & 1 & $\begin{array}{l}\text { Acil durum toplanma alanının olmaması ya da yetersiz } \\
\text { olması halinde afet sonrası toplanmanın sağlıklı bir şekilde } \\
\text { gerçekleşememe riski }\end{array}$ & 1 & 4 & 4 \\
\hline & 2 & $\begin{array}{l}\text { Okul bahçesi giriş-çıkışlarının güvenli olmaması sonucu } \\
\text { çlkışlarda arbede yaşanma riski }\end{array}$ & 1 & 5 & 5 \\
\hline \multirow{19}{*}{ 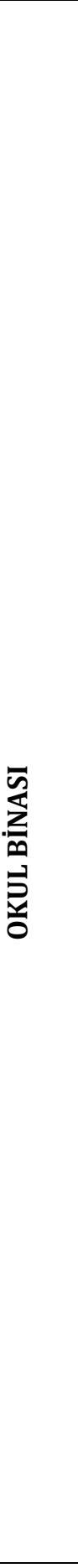 } & \multicolumn{5}{|c|}{ Sirkülasyon Alanları } \\
\hline & 3 & $\begin{array}{l}\text { Koridor genişliklerinin yeterli olmaması sonucu afet } \\
\text { sonrası tahliyenin sağlıklı bir şekilde gerçekleşememe } \\
\text { riski }\end{array}$ & 1 & 5 & 5 \\
\hline & 4 & $\begin{array}{l}\text { Bina ana çıkıș kapılarının açılış yönlerinin dışa doğru } \\
\text { olmaması sonucu afet sonrası tahliyenin sağlıklı bir } \\
\text { șekilde gerçekleșememe riski }\end{array}$ & 3 & 5 & 15 \\
\hline & 5 & $\begin{array}{l}\text { Çıkış kapılarında engelleyici eşyaların bulunması sonucu } \\
\text { afet sonrası tahliyenin sağlıklı bir şekilde gerçekleşememe } \\
\text { riski }\end{array}$ & 2 & 5 & 10 \\
\hline & 6 & $\begin{array}{l}\text { Merdiven ve koridorlardaki kaydırmaz } \text { bantların } \\
\text { yetersizliği sonucu afet sonrası tahliyenin sağlıklı bir } \\
\text { șekilde gerçekleşememe riski }\end{array}$ & 1 & 3 & 3 \\
\hline & 7 & $\begin{array}{l}\text { Koridorlarda pano, çerçeve vb eşyaların sağlıklı bir şekilde } \\
\text { sabitlenmemesi sonucu afet sırasında düşmesi riski }\end{array}$ & 1 & 3 & 3 \\
\hline & 8 & $\begin{array}{l}\text { Acil çıkış yönlendirmelerinin yetersizliği sonucu afet } \\
\text { sonrası tahliyenin sağlıklı bir şekilde gerçekleșeme riski }\end{array}$ & 1 & 2 & 2 \\
\hline & 9 & $\begin{array}{l}\text { Acil durum tahliye sirenlerinin çalışmaması sonucu afet } \\
\text { sonrası tahliyenin sağlıklı bir şekilde gerçekleşememe } \\
\text { riski }\end{array}$ & 3 & 4 & 12 \\
\hline & \multicolumn{5}{|c|}{ Eğitim Birimleri } \\
\hline & 10 & $\begin{array}{l}\text { Masa ve sıraların derslik içerisindeki yanlış yerleşimi } \\
\text { sonucunda afet sırasında camların parçalanması ve } \\
\text { öğrencilere zarar vermesi riski }\end{array}$ & 5 & 3 & 15 \\
\hline & 11 & $\begin{array}{l}\text { Dersliklerde bulunan mobilyaların (masa-sıra-kitaplık vb) } \\
\text { sabitlenmemesi sonucu devrilmesi riski }\end{array}$ & 5 & 5 & 25 \\
\hline & 12 & $\begin{array}{l}\text { Duvarlarda ve tavanda asılı olan pano, çerçeve, aydınlatma } \\
\text { vb eşyaların sabitlenmemesi sonucu düșmesi riski }\end{array}$ & 2 & 3 & 6 \\
\hline & 13 & $\begin{array}{l}\text { Eğitim birimlerinde camların parçalanmalarını önlemeye } \\
\text { karşı alınan güvenlik önlemlerinin alınmaması sonucu afet } \\
\text { sırasında camların parçalanması riski }\end{array}$ & 5 & 5 & 25 \\
\hline & 14 & $\begin{array}{l}\text { Eğitim birimlerinin kapılarının açılış yönlerinin dışa doğru } \\
\text { olmaması sonucu afet sonrası sınıflardan tahliyenin } \\
\text { sağlıklı bir şekilde gerçekleşememe riski }\end{array}$ & 1 & 5 & 5 \\
\hline & 15 & $\begin{array}{l}\text { Eğitim birimlerinin kapılarının etrafında acil çıkışa engel } \\
\text { olabilecek eşyaların olması sonucu afet sonrası tahliyenin } \\
\text { sağlıklı bir şekilde gerçekleşememe riski }\end{array}$ & 1 & 5 & 5 \\
\hline & 16 & $\begin{array}{l}\text { Kütüphanede bulunan mobilyaların sabitlenmemesi } \\
\text { sonucu devrilme riski }\end{array}$ & 3 & 4 & 12 \\
\hline & 17 & $\begin{array}{l}\text { Kütüphanede bulunan elektronik eşya ve kitapların } \\
\text { sabitlenmemesi sonucu düşme riski }\end{array}$ & 4 & 2 & 8 \\
\hline & 18 & $\begin{array}{l}\text { Laboratuvarlarda bulunan tüm kimyasal malzemelerin } \\
\text { güvenli yerleştirilmemesi sonucu devrilmesi ve dökülmesi } \\
\text { riski }\end{array}$ & 1 & 1 & 1 \\
\hline & \multicolumn{5}{|c|}{ İdari Birimler } \\
\hline
\end{tabular}


Risk Değerlendirme Matris Yöntemi Kullanarak Okullarda Deprem Kaynaklı Yapısal Olmayan Risklerin Olası Etkilerinin Belirlenmesi

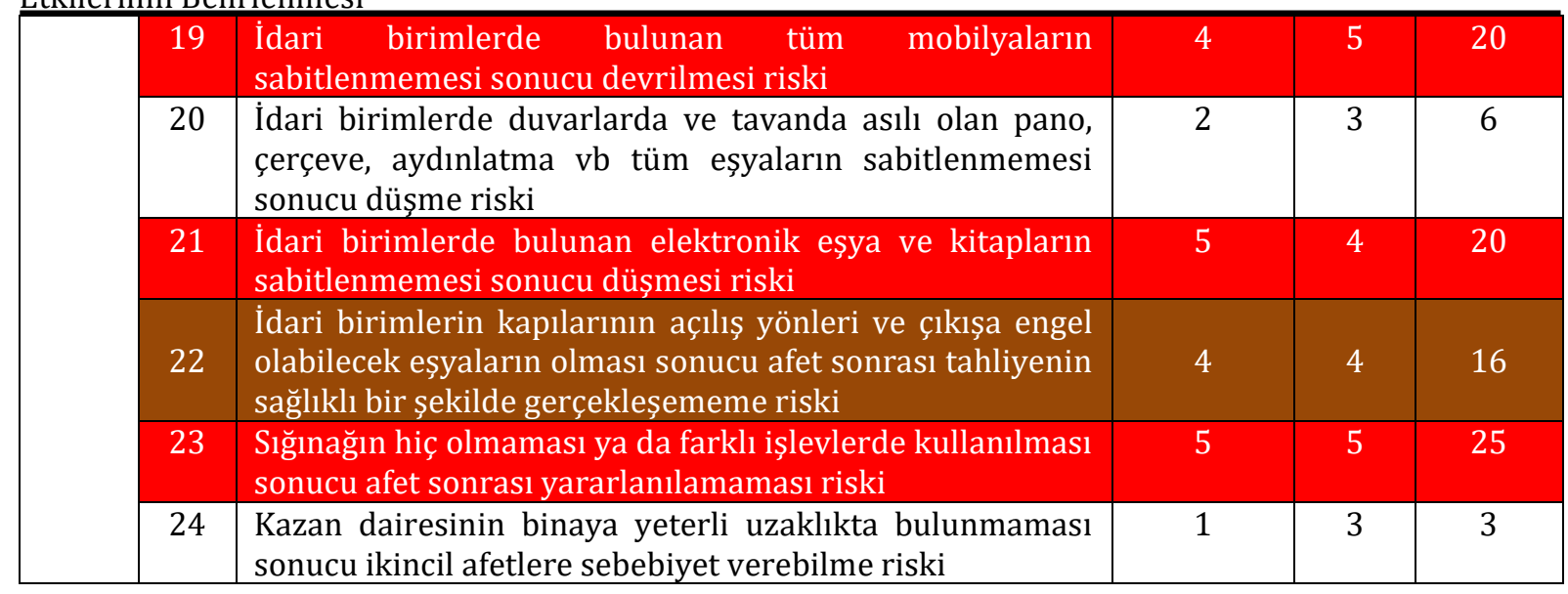

Tablo 6'da Risk değerlendirmesi yapılan 24 maddeden 5'i (11. 13. 19. 21. 23. maddeler) çok yüksek riskli olarak belirlenmiştir. Bu maddelerden 11. madde "Dersliklerde bulunan mobilyaların (masa-sıra-kitaplık vb) sabitlenmemesi sonucu devrilmesi riski" (25 puan risk değeri), 13. madde "Eğitim birimlerinde camların parçalanmalarını önlemeye karşı alınan güvenlik önlemlerinin alınmaması sonucu afet sırasında camların parçalanması riski" (25 puan risk değeri), 19. madde "İdari birimlerde bulunan tüm mobilyaların sabitlenmemesi sonucu devrilmesi riski" (20 puan risk değeri), 21. madde "İdari birimlerde bulunan elektronik eşya ve kitapların sabitlenmemesi sonucu düşmesi riski" (20 puan risk değeri), 23. madde "Sığınağın hiç olmaması ya da farklı işlevlerde kullanılması sonucu afet sonrası yararlanılamaması riski" (25 puan risk değeri) Tablo 5'e göre "Katlanılamaz Riskler" sınıfına girmektedir. Tablo 5'de risk seviyesi çok yüksek çıktığında (20-25 puan aralığında) "Katlanılamaz Riskler" sonucu elde edilmektedir. Bu sonuca göre Tablo 5'de katlanılamaz risklere yönelik "Belirlenen risk kabul edilebilir bir seviyeye düşürülünceye kadar iş başlatılmamalı, eğer devam eden bir faaliyet varsa derhal durdurulmalıdır. Gerçekleştirilen faaliyetlere rağmen riski düşürmek mümkün olmuyorsa, faaliyet engellenmelidir" tanımlaması ile eyleme geçilmesi tavsiye edilmektedir. Yüksek risk seviyesi de hafife alınmayacak bir risk seviyesidir. Yüksek risk seviyesinde Tablo 5'e göre "önemli riskler (15-16)" sonucuna göre "Belirlenen risk azaltılıncaya kadar iş başlatılmamalı eğer devam eden bir faaliyet varsa derhal durdurulmalıdır. Risk işin devam etmesi ile ilgiliyse acil önlem alınmalı ve bu önlemler sonucunda faaliyetin devamına karar verilmelidir" eylemi yer almaktadır.

Kaynaşlı Anadolu Lisesi'nin Tablo 6'ya göre yapılan risk değerlendirmesinde risk seviyeleri ve sayıları Şekil 5'de verilmiştir. Değerlendirme sonucunda 1 maddenin çok düşük, 11 maddenin düşük, 4 maddenin orta, 3 maddenin yüksek ve 5 maddenin çok yüksek risk seviyesinde yer aldığı bulunmuştur. Bu maddelerden "çok yüksek" ve "yüksek" risk seviyesinde tespit edilen maddelere ait risklerin giderilmesine yönelik eylemde bulunulması tavsiye edilmektedir.

Okulun risk değerlendirme seviyelerinin oransal olarak dağılımları Şekil 6'da verilmiştir. Değerlendirilen maddelerden \% 4'ü çok düşük, \% 46'sı düşük, \% 17'si orta, \% 12'si yüksek ve \% 21 'i çok yüksek risk seviyesi bulunmuştur. Risk değerlendirmesinde öne çıkan seviyelerden "yüksek" ve "çok yüksek" risk seviyeleri eyleme geçilmediğinde tehlikelere neden olabilecek seviyelerdir. Yüksek ve çok yüksek risk seviye oranlarına sahip okulun yapısal olmayan elemanlar bakımından maruz kalabileceği tehlike riskini de artırmaktadır. Bu bağlamda Kaynaşlı Anadolu Lisesi'nde yapılan risk değerlendirmesinde \% 12 yüksek, \% 21 çok yüksek risk seviyelerinin oransal toplamı \% 33 çıkmaktadır. Okulun yapısal olmayan elemanlar yönünden değerlendirilmesinde \% 33 risk seviyesi azımsanmayacak orandadır. Bu sebeple yüksek ve çok yüksek risklere sahip bulguların öncelikle çözümlemesine gidilmelidir. 


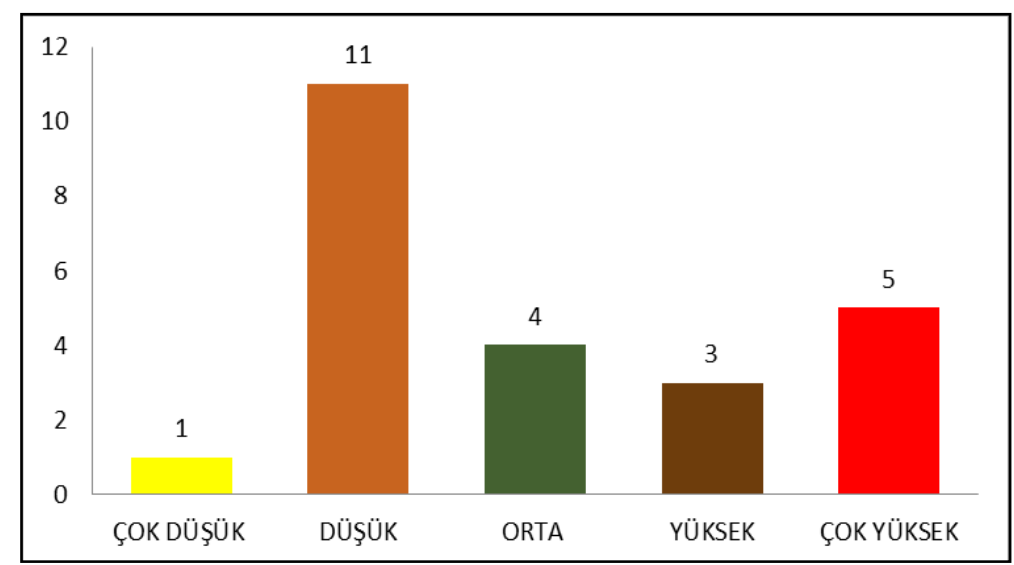

Şekil 5. Kaynaşlı Anadolu Lisesi risk değerlendirme seviyeleri

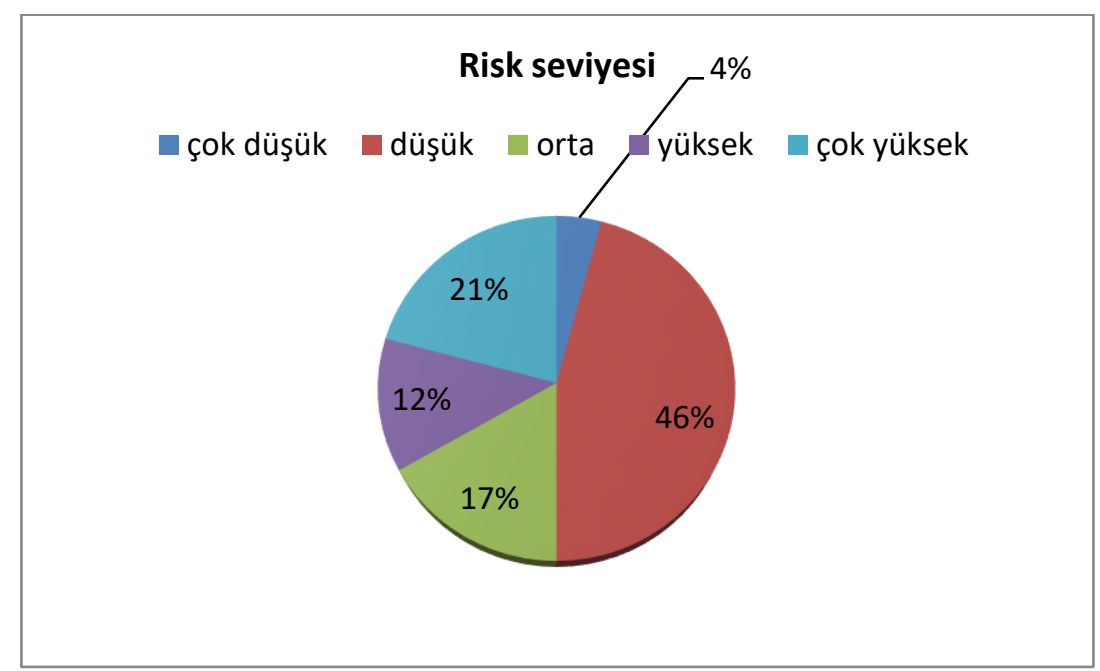

Şekil 6. Kaynaşlı Anadolu Lisesi risk değerlendirme oransal dağılımı

\subsubsection{Kaynaşlı Anadolu Lisesi'nde Risk Teşkil Edebilecek Bazı Bulgular}

Çalışma gurubuyla okulda yapılan yerinde incelemeler sonucunda tespit edilen bazı olumsuzluklar yapıcı eleştiri kapsamında aşağıda verilmektedir. Bu olumsuzlukların giderilmesi tehlikelerin olası etkilerinin minimum düzeye indirilmesini veya yok edilmesini sağlayabilecektir.

\section{Okulda belirgin bazı olumsuzluklar:}

- Okulda bulunan sığınağın amacının dışında (spor salonu) kullanımı söz konusudur.

- Dersliklerde bulunan öğrenci sıraları camlardan yeteri kadar uzakta değildir.

- Camlarda kırılmalarda parçalanarak zarar vermeyi engelleyici bir önlem bulunmamaktadır.

- Kantinde piknik tüpü açıkta durmakta ve güvenlik önlemi alınmamıştır.

- Öğretmenler odasında çok fazla dolap, sandalye bulunmakta ve sabit olmadıklarından ciddi risk teşkil etmektedirler (Şekil 7).

- 1. ve 2. kat koridorlarına sonradan mescit yapılarak acil çıkış kapısının önü daraltılmış, sadece 1 kişi geçebilecek genişlikte $50 \mathrm{~cm}$ civarı yer kalmıştır (Şekil 8).

- Okul ana giriş bölümünde sabitlenmemiş akvaryumun devrildiğinde kaymalara ve yaralanmalara neden olabilecektir (Şekil 9).

- Okul kütüphanesinde duvarlar boyunca sabitlenmemiş ayaklı birçok camlı dolaplar. Camlı ve ayaklı olmaları devrilme risklerini artırarak tehlikeye neden olabilirler (Şekil 10). 
Risk Değerlendirme Matris Yöntemi Kullanarak Okullarda Deprem Kaynaklı Yapısal Olmayan Risklerin Olası Etkilerinin Belirlenmesi

- Kimya Laboratuvarı sıkışık sandalye ve masa düzeni (Şekil 11).

- Kazan dairesinde atıl vaziyette dağınık eșyalar (Şekil 12).

- Ana giriş kapısı kısmında (anı köşesi) sabitlenmemiş yüksekliği derinliğinden oldukça fazla camlı dolaplar (Şekil 13).

- Okulun elektrik dağıtımını sağlayan elektrik odası (Elektrik dolapları sabitlenmemiş ve kenarlara yığılmış eşyalar) (Şekil 14).

\section{$\underline{\text { Okulda fotoğraflarla ifade edilen bazı olumsuzluklar: }}$}

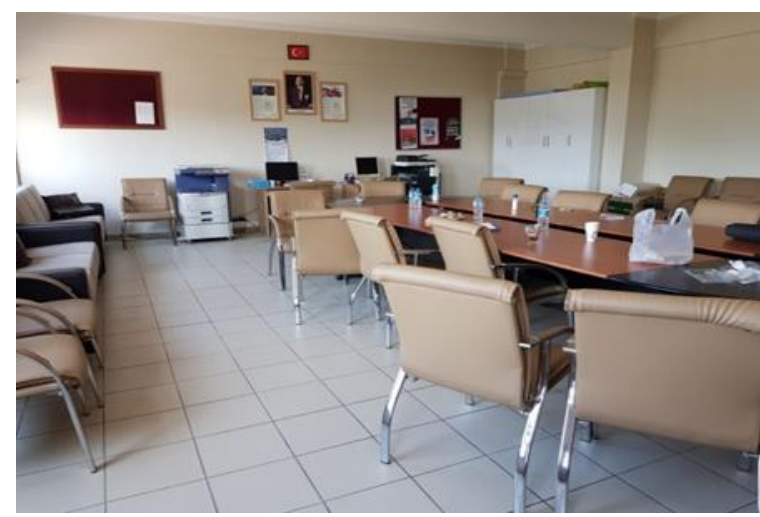

Şekil 7. Öğretmenler odası

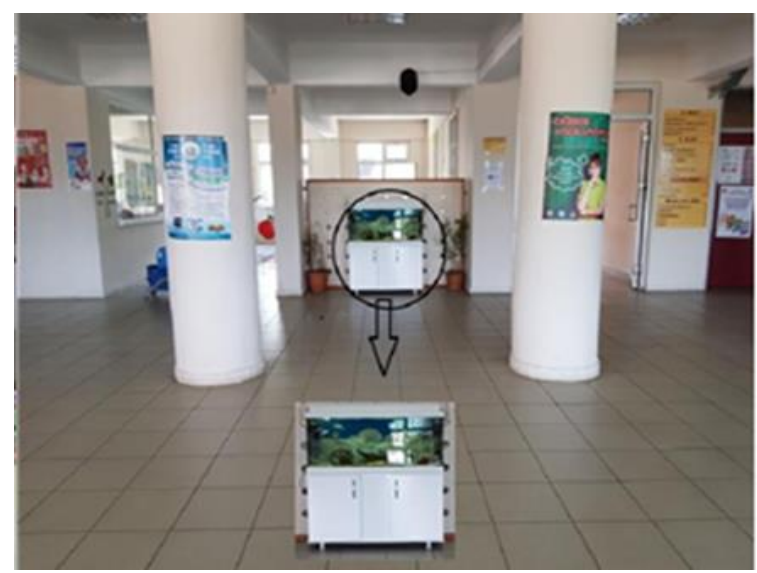

Şekil 9. Okulun ana giriș kısmında sabitlenmemiş akvaryum ve masası

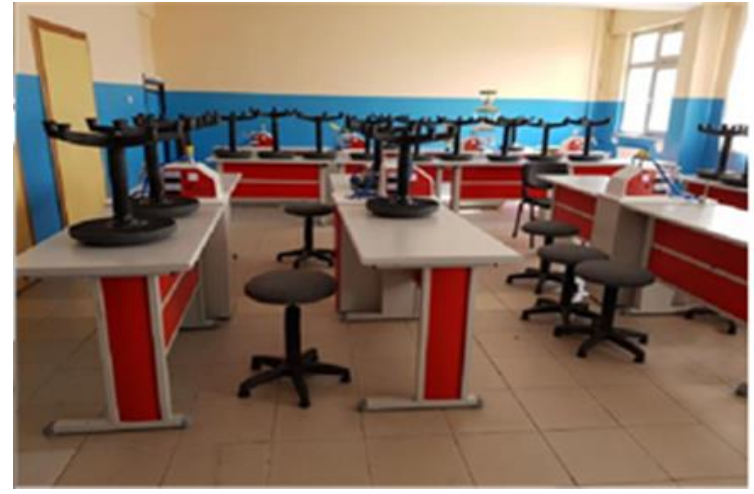

Şekil 11. Kimya Laboratuvarı

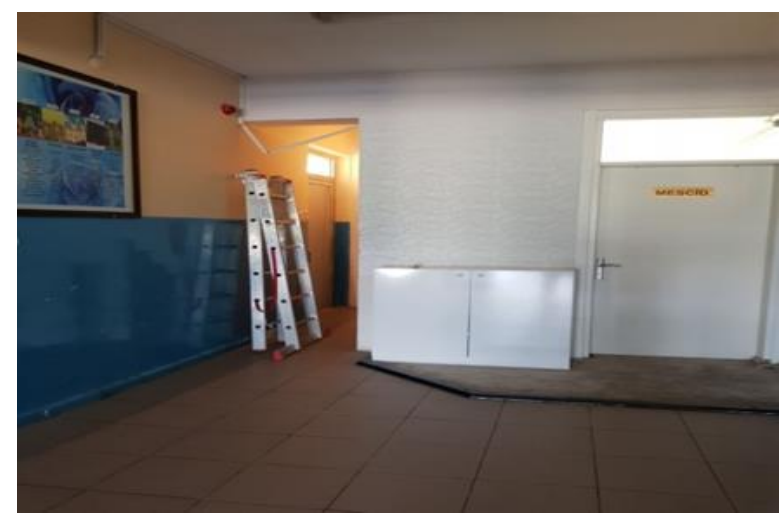

Şekil 8. Acil çıkış kapısı önünün kapanması

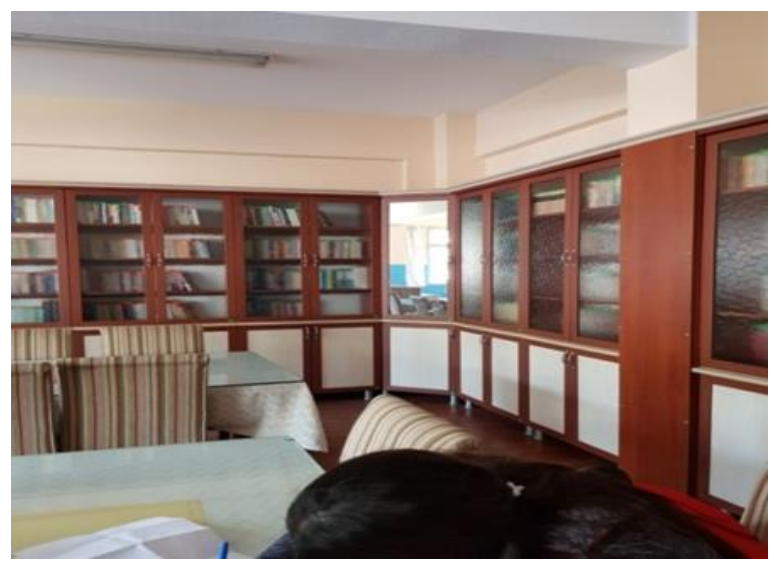

Şekil 10. Okul kütüphanesinde tehlikeye denen olabilecek dolaplar

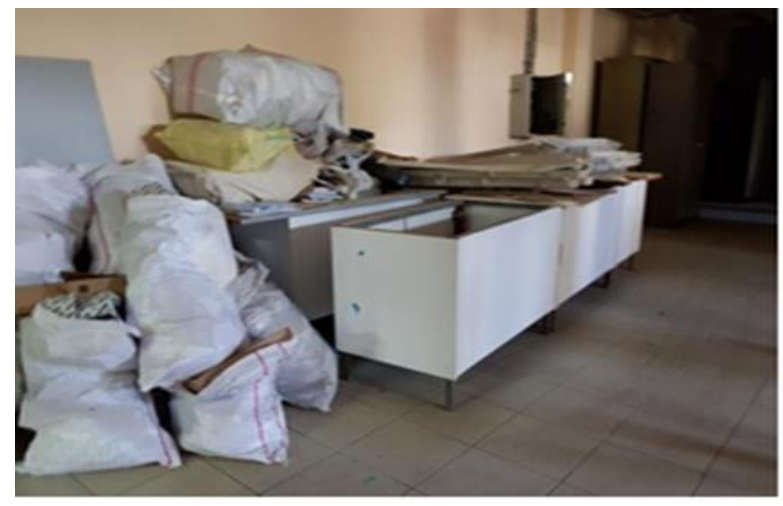

Şekil 12. Kazan dairesini ve düzensizlik 


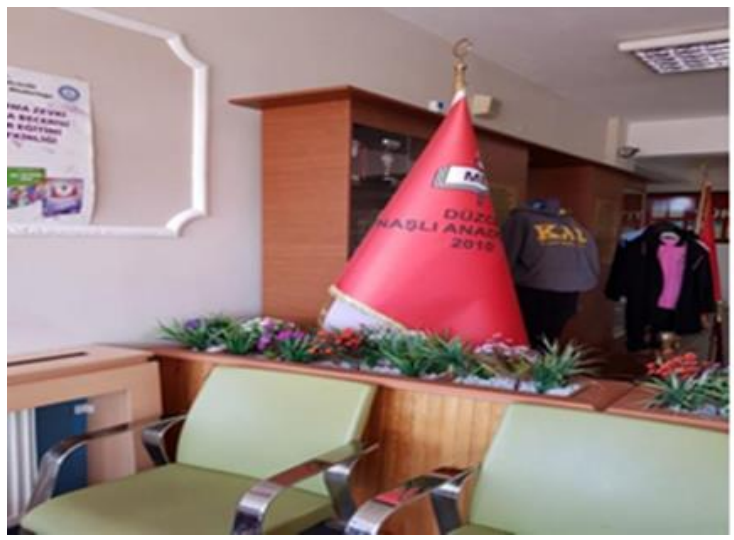

Şekil 13. Ana giriş kapısı ve yoğun eşya

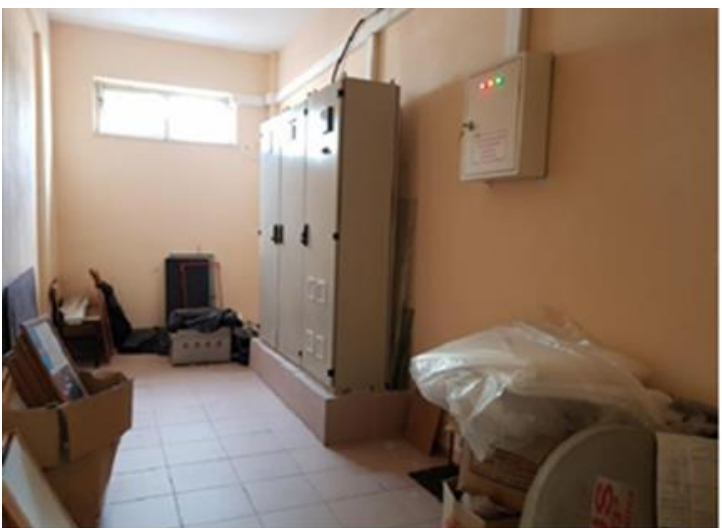

Şekil 14. Okulun elektrik dağıtımını sağlayan elektrik odası

\subsection{Kaynaşlı Anadolu Kalkınma Vakfı Ortaokulu}

Okul binası 12 Kasım 1999 depreminden sonra 2005-2006 yıllarında yapılmıştır. Bina bodrum artı 3 kattan oluşan 26 derslikli betonarme bir yapıdır. Okulun 21 öğretmeni ve 344 öğrencisi bulunmaktadır. Okul, geniş düz bir arazi üzerine kurulmuş, bahçesinde sportif faaliyetlerin yapılabildiği modern imkanlara sahip bir yapıdadır. Şekil 15'de okulun giriş ve bahçe alanını gösteren fotoğraf verilmiştir.

\subsubsection{Kaynaşlı Anadolu Kalkınma Vakfı Ortaokulu'nda Yapılan Çalışmalar}

Diğer okullarda olduğu gibi 24 soruluk anket okula uygulanmıştır. Anket yoluyla elde edilen veriler Tablo 4 ve Tablo 5'e göre değerlendirilerek risk seviyeleri belirlenmiştir. Risk seviyelerine göre riskin hangi eylem içerisinde değerlendirileceği bulunmuştur.

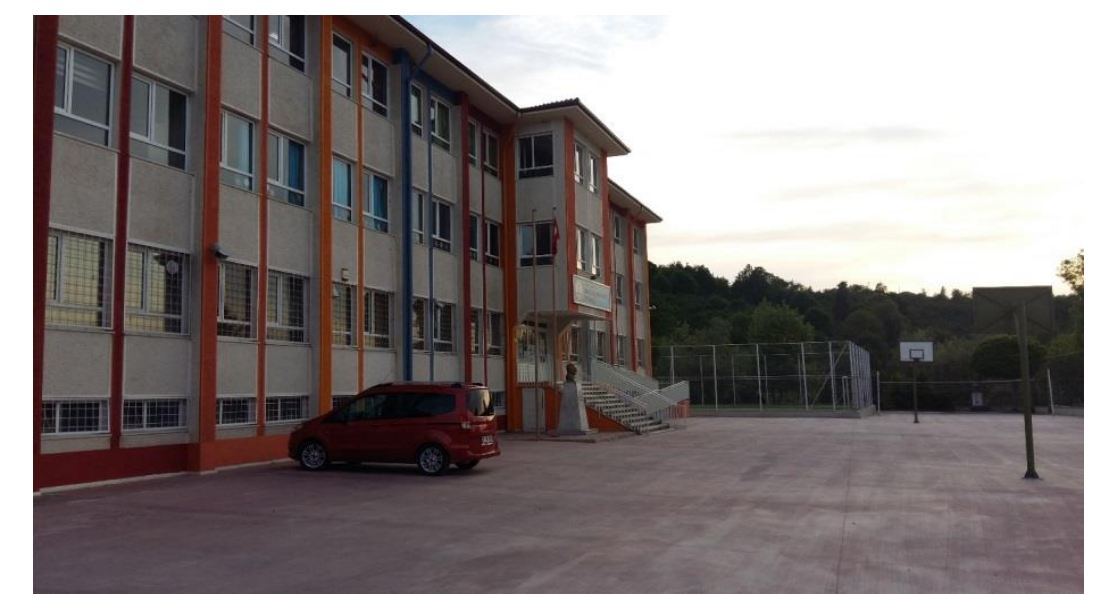

Şekil 15. Kaynaşlı Anadolu Kalkınma Vakfı Ortaokulu genel görünüş

Kaynaşlı Anadolu Vakfı Ortaokulunda yapılan risk değerlendirmesinde çalışmada 24 maddeden oluşan Tablo 7 kullanılmıștır. Tablo 7'ye göre 1 madde çok düşük, 10 madde düşük, 4 madde orta, 3 madde yüksek risk, 6 madde ise çok yüksek risk seviyesinde çıkmıştır (Şekil 16). Bu maddelerden özellikle "yüksek risk" seviyesinde çıkan 3 madde $(5,16,24$ maddeler) ile "çok yüksek" risk seviyesinde çıkan 6 madde $(4,9,11,19,21,23$ maddeler) üzerinde daha çok durularak olası tehlikenin giderilmesi için eyleme geçilmesi doğru olacaktır. 
Risk Değerlendirme Matris Yöntemi Kullanarak Okullarda Deprem Kaynaklı Yapısal Olmayan Risklerin Olası Etkilerinin Belirlenmesi

Şekil 17'de okulun risk değerlendirme oransal dağılımında \% 25 çok yüksek, \% 12 yüksek, \% 17 orta, \% 42 düșük ve \% 4 çok düșük olarak bulunmuştur. Tehlikeye daha fazla neden olabilecek seviyelerden "çok yüksek" (\% 25) ve "yüksek" (\% 12) risk seviyeleri toplam \% 37 bulunmuştur. Okulda öncelikle \% 37'lik dilimler olan çok yüksek ve yüksek risk seviyelerinin giderilmesi eylemine geçilmesi tavsiye edilmektedir.

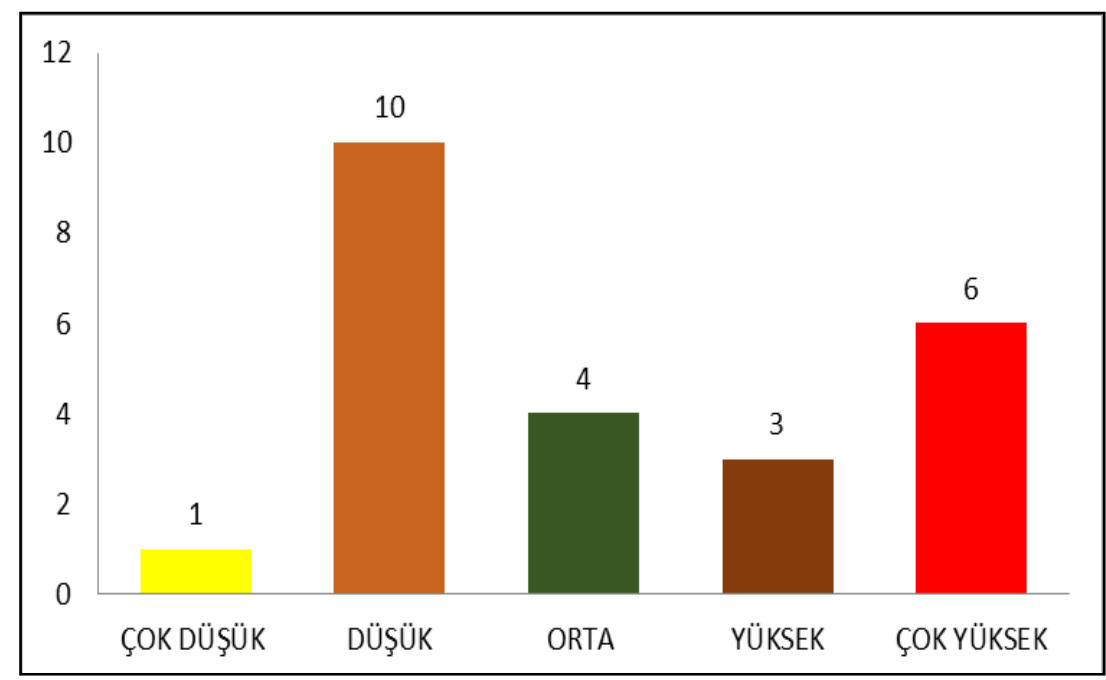

Şekil 16. Anadolu Kalkınma Vakfı Ortaokulu risk değerlendirme seviyeleri

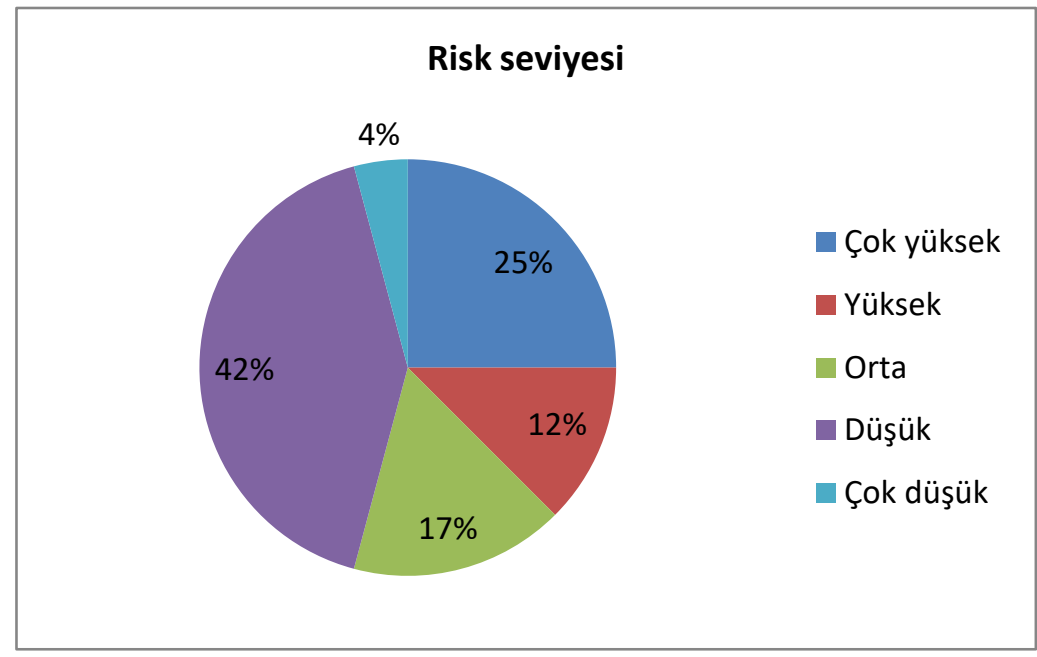

Şekil 17. Risk değerlendirme seviyelerinin oransal dağılımı

Tablo 7. Kontrol listeleri (anket çalışması)

\begin{tabular}{|c|c|c|c|c|c|}
\hline \multicolumn{6}{|c|}{ OKUL ADI: KAYNAȘLI ANADOLU KALKINMA VAKFI ORTAOKULU ANKET ÇALIŞMASI } \\
\hline & No & Risk & $\begin{array}{c}\text { Olma } \\
\text { İhtimali }\end{array}$ & Etki & $\begin{array}{c}\text { Risk } \\
\text { Değeri }\end{array}$ \\
\hline \multirow{2}{*}{ 苞 } & 1 & $\begin{array}{l}\text { Acil durum toplanma alanının olmaması ya da yetersiz } \\
\text { olması halinde afet sonrası toplanmanın sağlıklı bir şekilde } \\
\text { gerçekleşememe riski }\end{array}$ & 2 & 4 & 8 \\
\hline & 2 & $\begin{array}{l}\text { Okul bahçesi giriş-çıkışlarının güvenli olmaması sonucu } \\
\text { çıkışlarda arbede yaşanma riski }\end{array}$ & 1 & 5 & 5 \\
\hline
\end{tabular}







Risk Değerlendirme Matris Yöntemi Kullanarak Okullarda Deprem Kaynaklı Yapısal Olmayan Risklerin Olası Etkilerinin Belirlenmesi

\subsubsection{Anadolu Kalkınma Vakfı Ortaokulu Risk Teşkil Edebilecek Bazı Bulgular}

Okulda yerinde incelemeler ile tespit edilen bazı olumsuzluklar maddeler halinde aşağıda verilmiştir. Maddeler halinde verilen olumsuzlukların altında açıklayıcı olması amacıyla maddelerin anlaşılırlığını artırabilecek fotoğraflar bulunmaktadır.

Okulda belirgin bazı olumsuzluklar:

- Okulda bulunan sığınağın amacının dışında depo olarak kullanımı söz konusudur.

- Dersliklerde öğrenci sıraları camlardan yeteri kadar uzakta değiller.

- Camların kırılmalarda parçalanarak zarar vermeyi engelleyici film vb önlemler alınmamıştır.

- Ön bahçeye açılan farklı yerde iki çıkış kapısı camlı ağır metalden imal edilmiş ve içeri açılmaktadır. Camların kırılması ve kapıların içeri açılması acil bir durumda tahliyeyi zorlaştıracaktır.

- Fen laboratuvarında kullanılan tehlikeli araç gereçler için uyarı levhaları bulanmamakta, ayrıca dolaplar sabitlenmemiștir (Şekil 18).

- Okulun giriş ve çıkış için kullanılan kapısının yanında devrilmeye müsait birçok çiçek saksısı ve saksıların hemen üzerinde acil durumlar için alarm düğmesi bulunmaktadır (Şekil 19).

- Okulun giriş ve çıkışını sağlayan kapılar camlı metal kapılar olup içeri açılmaktadır (Şekil 20).

- Ayrı bir yerde elektrik odası bulunmamakta ve panolar dışarıda durmaktadır (Şekil 21).

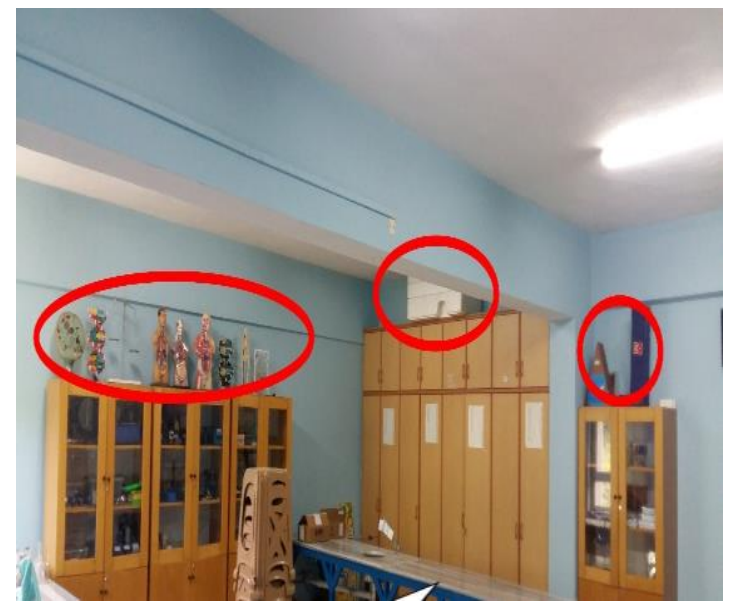

Şekil 18. Fen laboratuarı ve riskleri

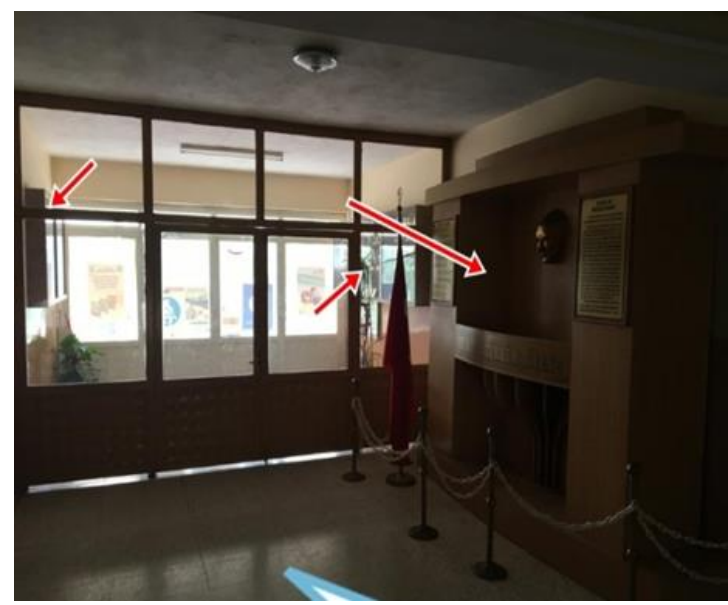

Şekil 20. Okulun giriş ve çıkışını sağlayan kapılar camlı metal kapılar

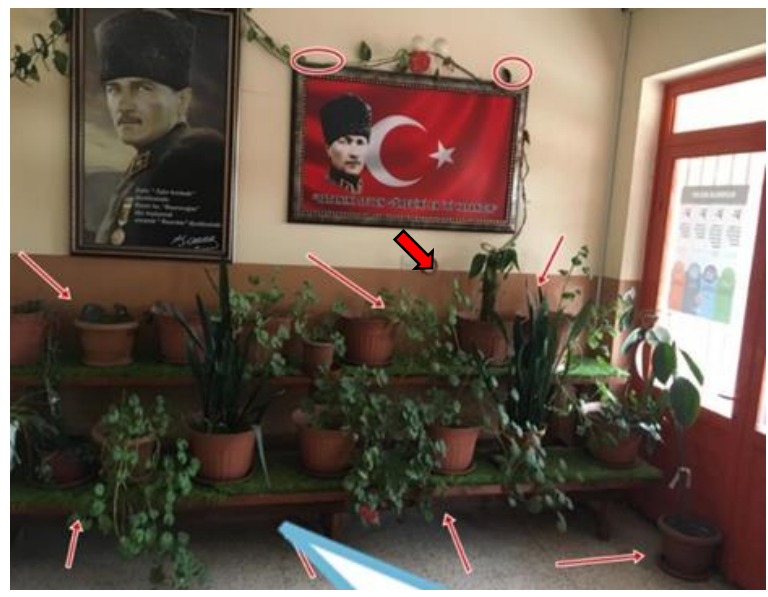

Şekil 19. Okulun giriş ve çıkışı

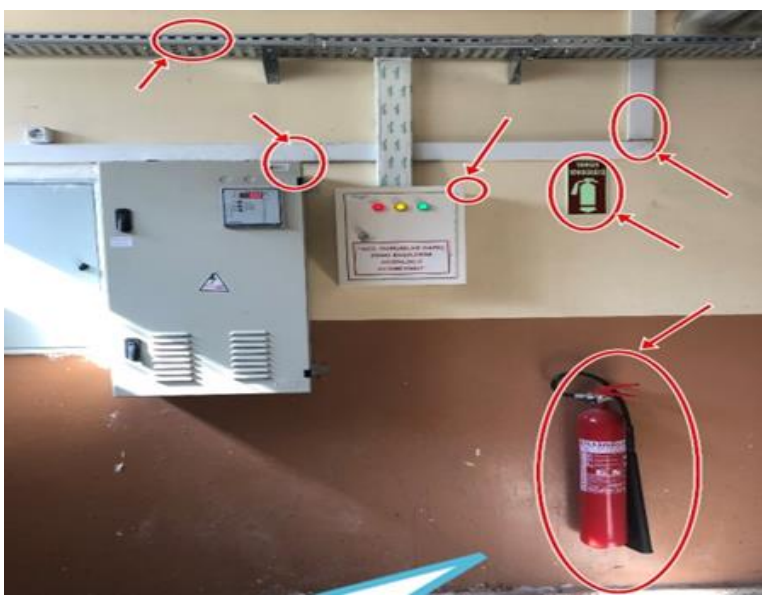

Şekil 21. Panolar ve tesisat durumu 


\subsection{Kaynaşlı Ilkokulu}

Kaynaşlı İlkokulu binası 2005 yılında tamamlanmış ve eğitime 2005-2006 eğitim-öğretim döneminde başlanmıştır. Zemin artı bir normal kattan oluşan 2 katlı yapı, betonarme karkas taşıyıcı sisteme sahiptir (Şekil 22). Okulda 23 derslik, 2 ana sınıfı, öğretmenler odası, müdür ve müdür yardımcısı odaları ve kantin bulunmaktadır. Okulun öğretmen sayısı 20, öğrenci sayısı ise 372'dir.

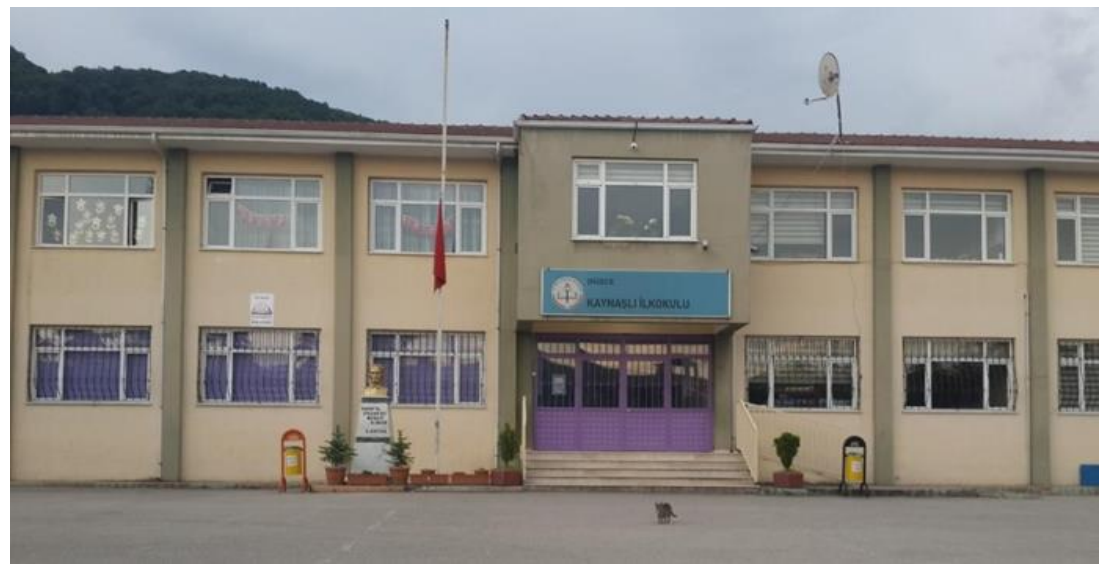

Şekil 22. Kaynaşlı İlkokulu giriş bölümünden görünüm

\subsubsection{Kaynaşlı İlkokulu'nda Yapılan Çalışmalar}

Çalışma grubuyla okula gidilerek diğer okullara uygulan kontrol listesi (anket) Kaynaşlı İlkokuluna da uygulanmıştır. Benzer şekilde anket yoluyla elde edilen verilerin analizleri Tablo 4 ve Tablo 5'e göre yapılarak risk seviyeleri belirlenmiștir. Tablo 8'de incelenen okulun kontrol listeleri ve her bir maddenin puanlamaları gösterilmiştir.

Yapılan anket çalışmasına göre Tablo 8 irdelendiğinde 1 madde çok düşük, 11 madde düşük, 3 madde orta, 2 madde yüksek ve 7 madde çok yüksek risk seviyesinde çıkmıştır. Yüksek risk seviyesinde çıkan 2 madde $(13,16$. maddeler), çok yüksek risk seviyesinde çıan 7 madde (4. 9. 11. 15. 19. 21. 23. maddeler)'dir. "Yüksek" ve "çok yüksek" seviyede çıkan toplam 9 maddenin ön plana alınarak eyleme geçilmesi tavsiye edilmektedir. Şekil 23'de risk seviyelerinin değerlendirilen maddeler içindeki dağılımları verilmiştir.

Kaynaşlı İlkokulu risk değerlendirme seviyelerinin oransal dağılımına baktığımızda; \% 29 çok yüksek, \% 8 yüksek, \% 13 orta, \% 46 düşük ve $\% 4$ çok düşük olarak bulunmuştur. Okullar için en fazla risk oluşturabilecek seviyelerden "çok yüksek" ve "yüksek" risk seviyelerinin toplam oranı \% 37 çıkmaktadır. Şekil 24'de Kaynaşlı İlkokulu risk seviyeleri oransal dağılımları verilmektedir.

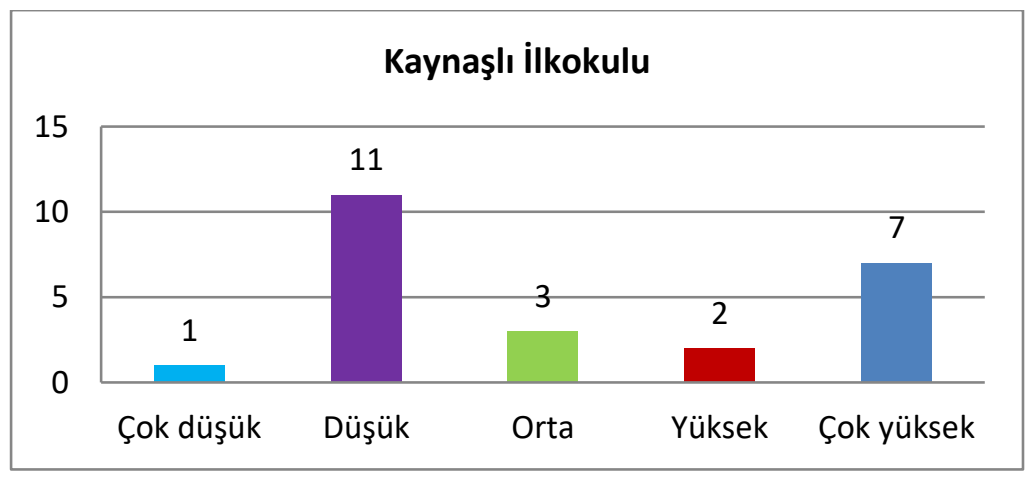

Şekil 23. Kaynaşlı İlkokulu risk değerlendirme seviyeleri 
Risk Değerlendirme Matris Yöntemi Kullanarak Okullarda Deprem Kaynaklı Yapısal Olmayan Risklerin Olası Etkilerinin Belirlenmesi

Tablo 8. Kontrol listeleri (anket çalıșması)

\begin{tabular}{|c|c|c|c|c|c|}
\hline \multicolumn{6}{|c|}{ OKUL ADI: KAYNAȘLI İLKOKULU ANKET ÇALIȘMASI } \\
\hline & No & Risk & $\begin{array}{c}\text { Olma } \\
\text { İhtimali }\end{array}$ & Etki & $\begin{array}{c}\text { Risk } \\
\text { Değeri }\end{array}$ \\
\hline \multirow{2}{*}{ 逽突 } & 1 & $\begin{array}{l}\text { Acil durum toplanma alanının olmaması ya da yetersiz } \\
\text { olması halinde afet sonrası toplanmanın sağlıklı bir } \\
\text { şekilde gerçekleşememe riski }\end{array}$ & 1 & 4 & 4 \\
\hline & 2 & $\begin{array}{l}\text { Okul bahçesi giriş-çıkışlarının güvenli olmaması sonucu } \\
\text { çıkışlarda arbede yaşanma riski }\end{array}$ & 2 & 5 & 10 \\
\hline \multirow{17}{*}{ 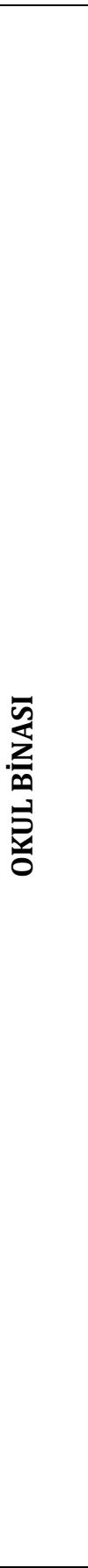 } & \multicolumn{5}{|c|}{ Sirkülasyon Alanları } \\
\hline & 3 & $\begin{array}{l}\text { Koridor genişliklerinin yeterli olmaması sonucu afet } \\
\text { sonrası tahliyenin sağlıklı bir şekilde gerçekleşememe } \\
\text { riski }\end{array}$ & 1 & 5 & 5 \\
\hline & 4 & $\begin{array}{l}\text { Bina ana çıkış kapılarının açılış yönlerinin dışa doğru } \\
\text { olmaması sonucu afet sonrası tahliyenin sağlıklı bir } \\
\text { șekilde gerçekleșememe riski }\end{array}$ & 5 & 5 & 25 \\
\hline & 5 & $\begin{array}{l}\text { Çıkış kapılarında engelleyici eşyaların bulunması sonucu } \\
\text { afet sonrası tahliyenin sağlıklı bir şekilde } \\
\text { gerçekleșememe riski }\end{array}$ & 1 & 5 & 5 \\
\hline & 6 & $\begin{array}{l}\text { Merdiven ve koridorlardaki kaydırmaz bantların } \\
\text { yetersizliği sonucu afet sonrası tahliyenin sağlıklı bir } \\
\text { şekilde gerçekleşememe riski }\end{array}$ & 2 & 3 & 6 \\
\hline & 7 & $\begin{array}{l}\text { Koridorlarda pano, çerçeve vb eşyaların sağlıklı bir } \\
\text { șekilde sabitlenmemesi sonucu afet sırasında düşmesi } \\
\text { riski }\end{array}$ & 1 & 3 & 3 \\
\hline & 8 & $\begin{array}{l}\text { Acil çıkış yönlendirmelerinin yetersizliği sonucu afet } \\
\text { sonrası tahliyenin sağlıklı bir şekilde gerçekleșeme riski }\end{array}$ & 1 & 2 & 2 \\
\hline & 9 & $\begin{array}{l}\text { Acil durum tahliye sirenlerinin çalışmaması sonucu afet } \\
\text { sonrası tahliyenin sağlıklı bir şekilde gerçekleşememe } \\
\text { riski }\end{array}$ & 5 & 4 & 20 \\
\hline & \multicolumn{5}{|c|}{ Eğitim Birimleri } \\
\hline & 10 & $\begin{array}{l}\text { Masa ve sıraların derslik içerisindeki yanlış yerleşimi } \\
\text { sonucunda afet sırasında camların parçalanması ve } \\
\text { öğrencilere zarar vermesi riski }\end{array}$ & 4 & 3 & 12 \\
\hline & 11 & $\begin{array}{l}\text { Dersliklerde bulunan mobilyaların (masa-sıra-kitaplık } \\
\text { vb) sabitlenmemesi sonucu devrilmesi riski }\end{array}$ & 5 & 5 & 25 \\
\hline & 12 & $\begin{array}{l}\text { Duvarlarda ve tavanda asllı olan pano, çerçeve, } \\
\text { aydınlatma vb eşyaların sabitlenmemesi sonucu düşmesi } \\
\text { riski }\end{array}$ & 2 & 3 & 6 \\
\hline & 13 & $\begin{array}{l}\text { Eğitim birimlerinde camların parçalanmalarını } \\
\text { önlemeye karşı alınan güvenlik önlemlerinin alınmaması } \\
\text { sonucu afet sırasında camların parçalanması riski }\end{array}$ & 3 & 5 & 15 \\
\hline & 14 & $\begin{array}{l}\text { Eğitim birimlerinin kapılarının açllış yönlerinin dışa } \\
\text { doğru olmaması sonucu afet sonrası sınıflardan } \\
\text { tahliyenin sağlıklı bir şekilde gerçekleșememe riski }\end{array}$ & 1 & 5 & 5 \\
\hline & 15 & $\begin{array}{l}\text { Eğitim birimlerinin kapılarının etrafında acil çılkışa engel } \\
\text { olabilecek eşyaların olması sonucu afet sonrası } \\
\text { tahliyenin sağlıklı bir şekilde gerçekleşememe riski }\end{array}$ & 5 & 5 & 25 \\
\hline & 16 & $\begin{array}{l}\text { Kütüphanede bulunan mobilyaların sabitlenmemesi } \\
\text { sonucu devrilme riski }\end{array}$ & 4 & 4 & 16 \\
\hline & 17 & $\begin{array}{l}\text { Kütüphanede bulunan elektronik eşya ve kitapların } \\
\text { sabitlenmemesi sonucu düșme riski }\end{array}$ & 5 & 2 & 10 \\
\hline
\end{tabular}


Afet ve Risk Dergisi Cilt: 2 Sayı: 2, 2019 (128-152)

Hüseyin BAYRAKTAR, Elif SAHTIYANCI, Ali KURU

\begin{tabular}{|c|c|c|c|c|}
\hline 18 & $\begin{array}{l}\text { Laboratuvarlarda bulunan tüm kimyasal malzemelerin } \\
\text { güvenli yerleştirilmemesi sonucu devrilmesi } \\
\text { dökülmesi riski }\end{array}$ & 1 & 1 & 1 \\
\hline \multicolumn{5}{|c|}{ İdari Birimler } \\
\hline 19 & $\begin{array}{l}\text { İdari birimlerde bulunan tüm } \\
\text { sabitlenmemesi sonucu devrilmesi riski }\end{array}$ & 5 & 5 & 25 \\
\hline 20 & $\begin{array}{l}\text { İdari birimlerde duvarlarda ve tavanda asılı olan pano, } \\
\text { çerçeve, aydınlatma vb tüm eșyaların sabitlenmemesi } \\
\text { sonucu düșme riski }\end{array}$ & 2 & 3 & 6 \\
\hline 21 & $\begin{array}{l}\text { İdari birimlerde bulunan elektronik eșya ve kitapların } \\
\text { sabitlenmemesi sonucu düșmesi riski }\end{array}$ & 5 & 4 & 20 \\
\hline 22 & $\begin{array}{l}\text { İdari birimlerin kapılarının açllış yönleri ve çıkışa engel } \\
\text { olabilecek eşyaların olması sonucu afet sonrası } \\
\text { tahliyenin sağlıklı bir șekilde gerçekleșeme riski }\end{array}$ & 1 & 4 & 4 \\
\hline 23 & $\begin{array}{l}\text { Sığınağın hiç olmaması ya da farklı işlevlerde } \\
\text { kullanılması sonucu afet sonrası yararlanılamaması riski }\end{array}$ & 5 & 5 & 25 \\
\hline 24 & $\begin{array}{l}\text { Kazan dairesinin binaya yeterli uzaklıkta bulunmaması } \\
\text { sonucu ikincil afetlere sebebiyet verebilme riski }\end{array}$ & 1 & 3 & 3 \\
\hline
\end{tabular}

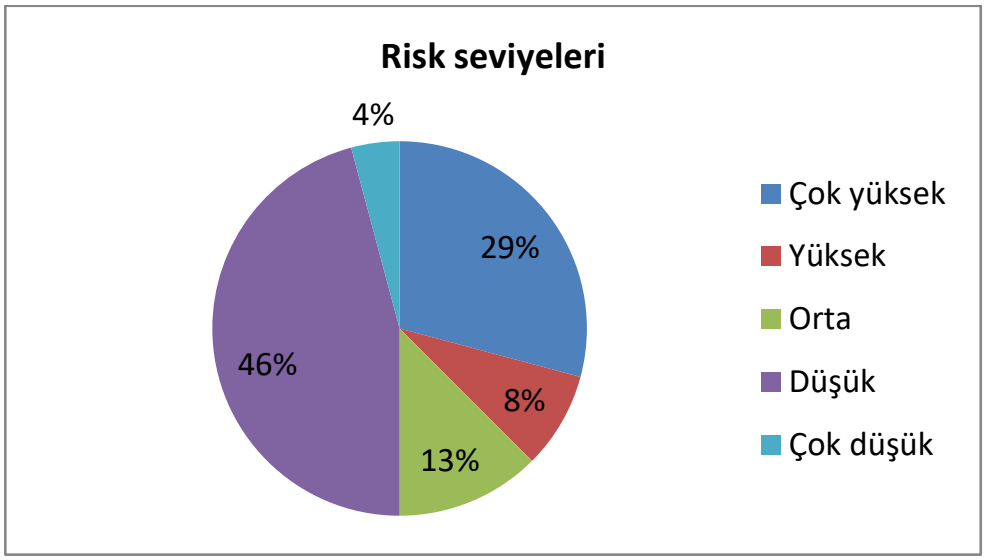

Şekil 24. Kaynaşlı İlkokulu risk seviyeleri oransal dağılımı

\subsubsection{Kaynașlı İlkokulu risk teșkil edebilecek bazı bulgular}

Okulda yapılan detaylı incelemeler sonucunda tehlikeye sebep olabilecek bazı olumsuzluklar maddeler halinde aşağıda verilmiştir. Okulda küçük yaş gurubunda olan anaokulu ve ilkokul öğrencilerinin bulunması tehlikeye maruz kalmalarında kritik etkiye sahip olmalarına neden olmaktadır. Bu yüzden Kaynaşlı İlkokulunda tespit edilen risklerin giderilmesi daha da önem arz etmektedir.

Okulda belirgin bazı olumsuzluklar:

- Ana sınıfı öğrencilerinin giriş için kullandığı okulun yan bölümünde giriş holü dar bırakılmış, tahliye için yeterli genişlikte değildir (Şekil 25).

- Okulun camlı ana giriş kapısı içe doğru açılmakta ve camların kırılmasına karşı herhangi bir önlem alınmamıştır (Şekil 26).

- Dersliklerin bazılarında çıkış kapılarının hemen yanında derinliği az, yüksekliği fazla sabitlenmemiş dolaplar vardır. Bu dolaplar olası bir acil durumda devrilerek tahliyeyi engelleyebilecektir (Şekil 27).

- Dersliklerde kapı yanında olmayıp öğretmen masasının ya da öğrenci sıralarının hemen arkasında sabitlenmemiş, üzerilerinde ve içlerinde kitap vb eşyalar bulunan camlı dolaplar vardır (Şekil 28). 
Risk Değerlendirme Matris Yöntemi Kullanarak Okullarda Deprem Kaynaklı Yapısal Olmayan Risklerin Olası Etkilerinin Belirlenmesi

- Öğrenci sıralarının hemen arkasında sabitlenmemiş ayaklı camlı dolap (Şekil 29).

- Kütüphanede sabitlenmemiș masa üstü bilgisayarlar ve tavanı asma tavan yapılmıș (Asma tavanlar deprem sırasında risk oluşturabilmektedir) (Şekil 30).

- Ana sınıfında masa üstü bilgisayarlar, yazıcılar ve camlı dolaplar sabitlenmemiștir (Şekil 31).

- Öğretmenler odasının çıkış kapısının hemen yanında sabitlenmemiş vestiyer dolap ve oda içerisinde sabitlenmemiş bir dolap daha vardır (Şekil 32).

- Dersliklerde bazı dolapların üst raflarına, en üst kısımlarına alt raflarda olması gereken ağır eşyalar yerleştirilmiştir. Bu eşyalar olası acil durumda devrilerek yaralanmalara veya geçiş yollarının kapanmasına sebep olabilecekleridir.

- Tüm camlarda kırılmalara karşı herhangi bir önlem alınmamıştır.

- Dersliklerde sıra yerleşimi güvenli olmayıp çok sıkışık düzende ve öğrenci sıraları pencerelerden güvenli uzaklıklarda değildir.

- Tüm dersliklerde bulunan masa üstü bilgisayar ve yazıcılarda herhangi bir sabitleme yapılmamiştır.

- Kütüphane tavanı asma tavandır. Asma tavanlar deprem anında tehlikelere neden olabilmektedir. Ayrıca kütüphanede masa üstü bilgisayarların sabitlenmeleri yapılmamıștır.

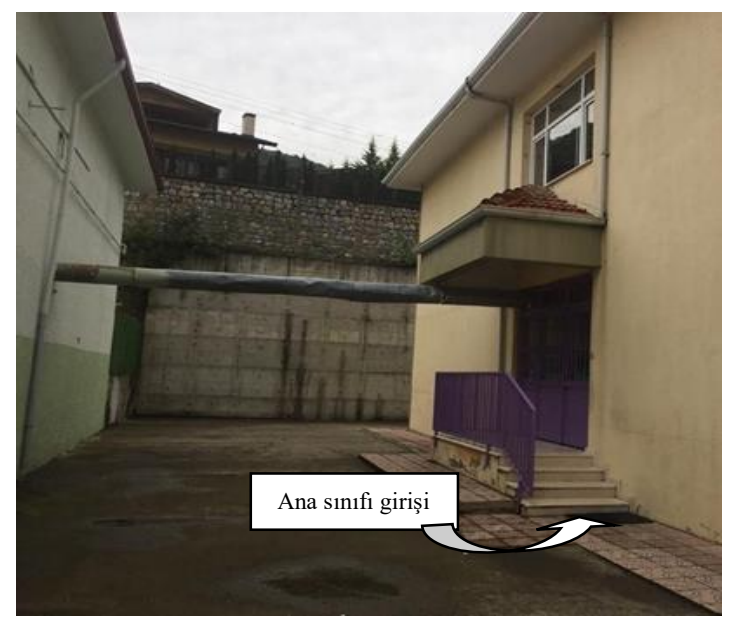

Şekil 25. Ana sınıfı girişi

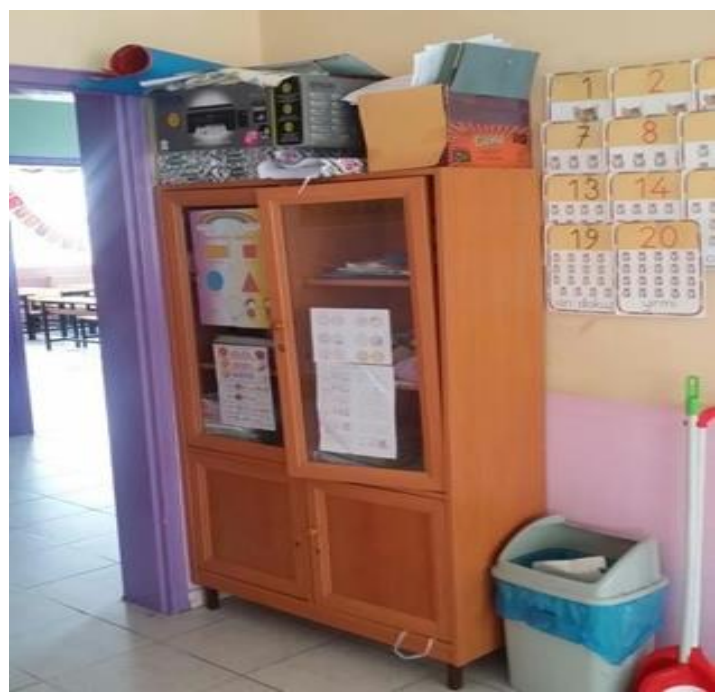

Şekil 27. Derslik giriş kısmı

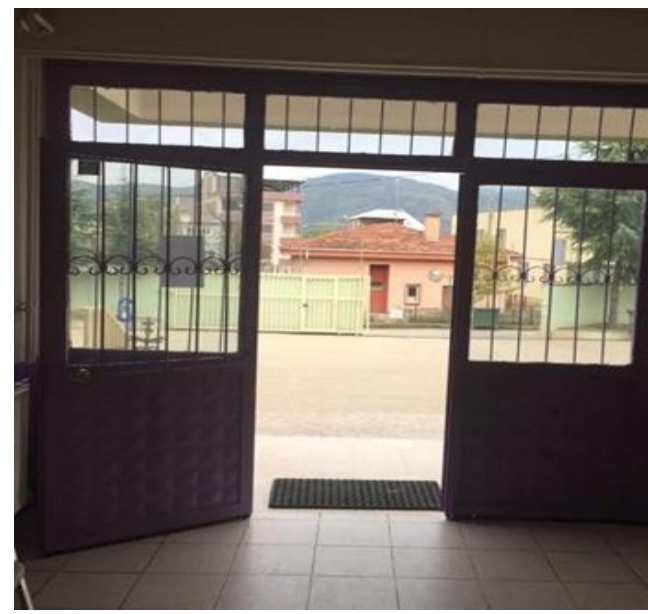

Şekil 26. Okulun giriş kapısı

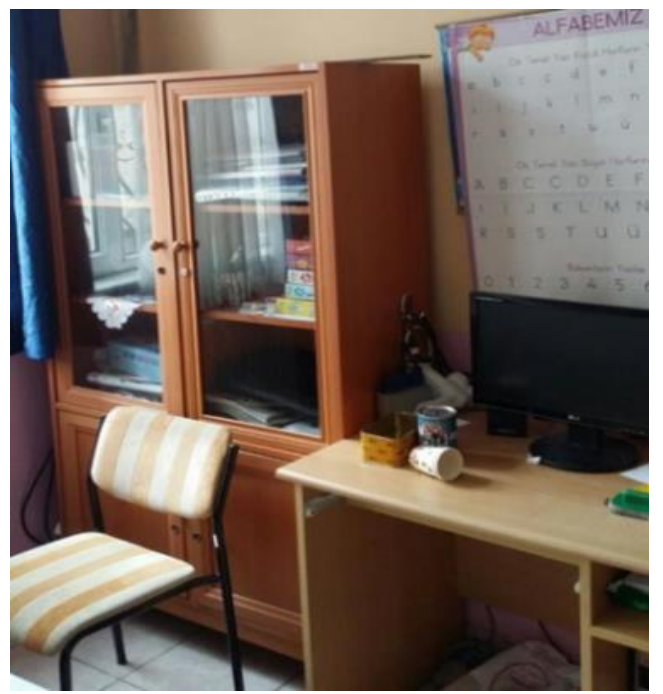

Şekil 28. Öğretmen masası ve camlı dolap 


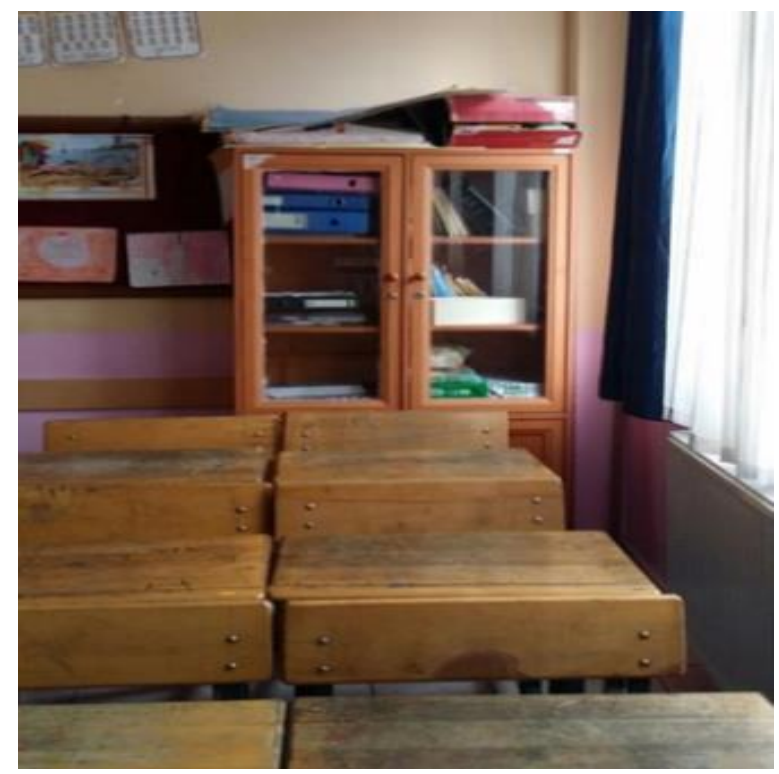

Şekil 29. Derslik sıkışık düzen ve camlı dolap

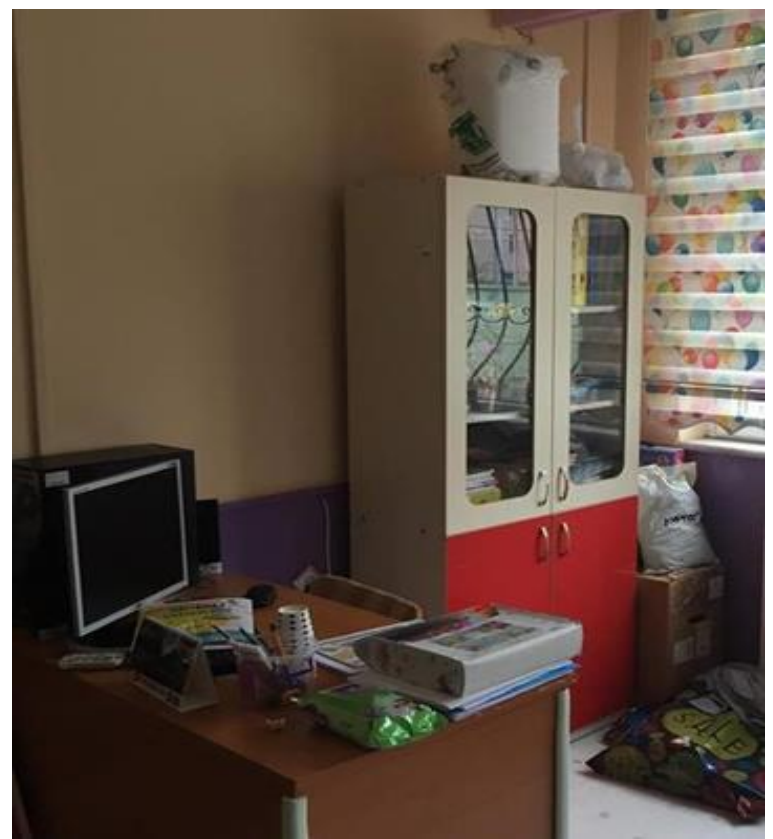

Şekil 31. Ana sınıfi ve risk oluşturabilecek eşyalar

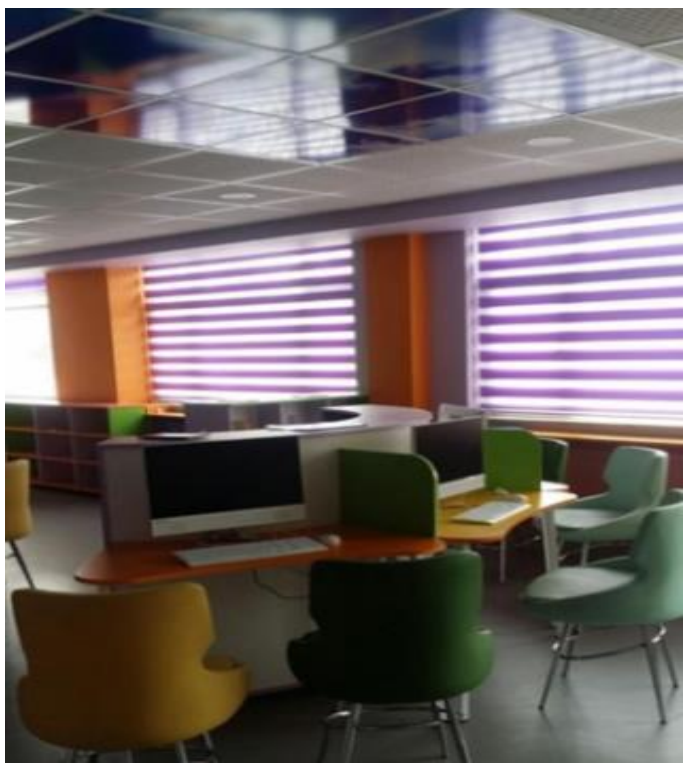

Şekil 30. Kütüphaneden görünüm

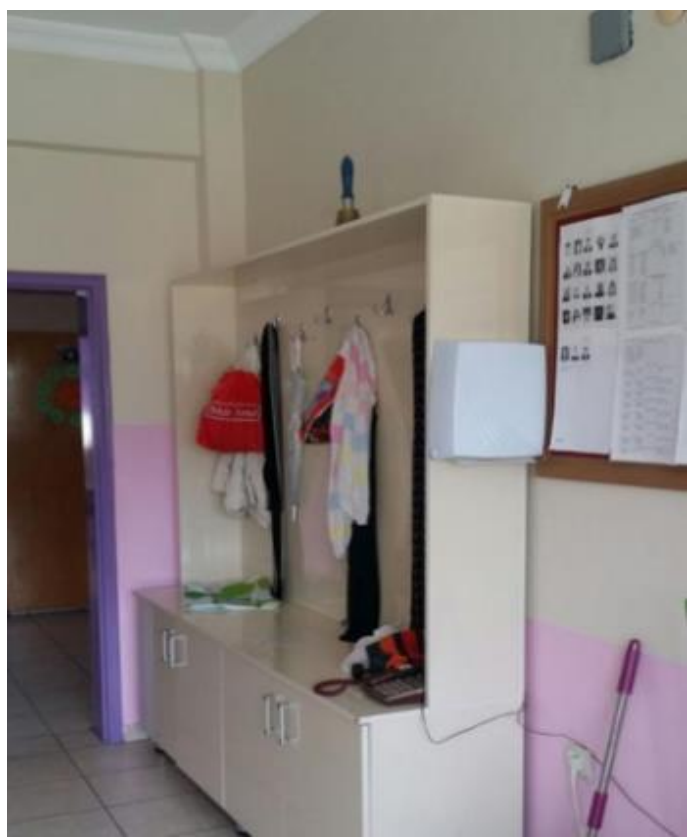

Şekil 32. Öğretmenler odası çıkış kapısı

\section{SONUÇ VE DEĞERLENDİRME}

Ülkemizde yapısal olmayan elemanların okullarda risk oluşturmaması için iki yol izlenebilir. Birincisi, henüz proje aşamasında olan okullar için gerekli mevzuatlarda belirlenmiş yapısal olmayan elemanların risk oluşturmaması için nerelerde ve nasıl yerleștirileceği vb izlenecek yolun belirlenmesidir. İkincisi ise daha önce yapılan okullar için Bakanlık nezdinde kurulacak alanında uzman ekipler ya da risk tespiti alanında akredite olmuş özel teşebbüslere risk değerlendirmesi ihale edilerek hizmet yoluyla yapısal olmayan elemanların mevcut durumları, risk 
Risk Değerlendirme Matris Yöntemi Kullanarak Okullarda Deprem Kaynaklı Yapısal Olmayan Risklerin Olası Etkilerinin Belirlenmesi

oluşturabileceklerin tespiti, yer değiștirme ya da sabitlemelerin yaptırılması gibi adımlar atılarak okullarda gelecekte oluşabilecek tehlikelerin ortadan kaldırılması sağlanabilecektir.

Ülkemizde Milli Eğitim Bakanlığına bağlı okullarda idarecilerin (yöneticilerin) değişmesi sık rastlanan bir durumdur. Bu durum her alanda yönetim anlayışını da değiștirebilmektedir. Örneğin herhangi bir okulda yeni idareciler göreve geldiğinde sinıflara rastgele dolaplar yerleştirilebilmekte, koridorlara çiçek saksıları vb konulmakta ya da okul girişinin hemen karşısına güzel görüntü için koca bir akvaryum koyulabilmektedir. Bu örnekleri çoğaltmak mümkündür. Bu davranışların hemen hepsi iyi niyetle yapılan davranışlardır. Fakat afet anında tehlikeye sebep olabilecek riskler göz ardı edilmemelidir. Okullarda yapısal olmayan elemanlarla ilgili süreç kişilere göre değil bölgenin afet potansiyeline göre belirlenen kurallara göre yapılmalıdır.

Yapısal risklere karşı ülkemizde yönetmelikler yeterli ve kapsamlıdır. Esas problem yönetmeliklerin yerine getirilmesinde ve denetiminde yetersizliklerin bulunmasıdır. Buna yönelik çalışmaların yapıldığı bilinmekle beraber önceliğin tehlikelere karşı hep birlikte bir mücadelenin içerisine girilebilmesidir. Yapısal olmayan tehlikelere karşı ise ne yazık ki yönetmeliklerde kesinlik arz eden ayrıntılar çok bulunmamaktadır. Örneğin Milli Eğitim Bakanlığı Yatırımlar ve Tesisler Dairesi Başkanlığı tarafından hazırlanan "Eğitim Yapıları Mimari Proje Hazırlanması Genel İlkeleri" ile özel projelerin çevresel şartlara ve mevzuata uygun, güvenli, ekonomik, estetik, kullanışlı ve nitelikli eğitim ortamlarının oluşturulması hedeflenmiştir. Fakat genel ilkeler arasında hiçbir yerde afet, risk, yapısal olmayan gibi kelimeler ve bunlara yönelik ifadeler yer almamaktadır. Sadece bir yerde "Projeler; yürürlükteki mevzuata, Deprem Bölgelerinde Yapılacak Binalar Hakkında Yönetmelik, Binalarda Enerji Performansı Yönetmeliği, Sığınak Yönetmeliği, Binaların Yangından Korunması Hakkında Yönetmelik, engellilerle ilgili TS 9111 ve TS 12576 nolu standartlara, Genelge ve diğer mevzuata uygun hazırlanmalıdır" ifadesinde "deprem" kelimesi geçmektedir. Yapısal olmayan elemanların plan ve projelerde nasıl konulması, yerleştirilmesi, korunma yolları, vb hakkında bilgiler yer almamaktadır. Bu durum genel olarak okullarda yapısal olmayan elemanların risk etkileri düşünülmeden gelişigüzel okul içerisinde derslik, koridor vb yerlere yerleştirilmesine neden olmaktadır. Okullar tarafından hazırlanması gereken okul afet ve acil durum yönetimi planlarında yapısal olmayan elemanlardan kaynaklı risklerin belirlenmesi ve tedbir alınması yerinde olacaktır.

Yapısal olmayan elemanların okulların daha projelendirilme aşamasında göz önüne alınması ve gerekli mevzuatlarda yer alması yapısal olmayan elemanlardan kaynaklı risklerin ortadan kalkmasını sağlayabilecektir. Okullarda yapısal olmayan risklere karşı Milli Eğitim Bakanlı̆̆ı merkezli bir çalışma ile tüm okulların yapması ve yapmaması gerekli çalışmaları bir yönetmelik kapsamında hazırlayıp sunması ile okullarda risklere karşı sürdürülebilir bir yapılanma sağlanabilecektir. Bu sayede bir okulda idareci değişse de ona izin verilen çerçevede değişiklikleri yapması mümkün olabilecektir.

Çalışmada okullara ait elde edilen risk değerlendirmelerine göre "çok yüksek" ve "yüksek" risk seviyelerine sahip maddelerin öncelikle giderilmesi ve sonra diğer risk seviye maddelerine geçilmesi önerilmektedir. Çünkü depremin ne zaman gerçekleşeceği kesin olarak bilinememektedir. Bu yüzden büyük tehlikelere neden olabilecek risklerin bir an önce ortadan kaldırılması hayati önem taşımaktadır.

Çalışmamızda her bir okulun kritik seviyeler olan "yüksek" ve "çok yüksek" risk seviyesine sahip olma oranı toplamı o okulun risk değerlendirmesindeki mevcut durumunu görmemizi sağlamaktadır. Elde edilen sonuçlara göre üç okulun risk seviyeleri; Kaynaşlı Anadolu Lisesi risk değerlendirme sonucunda \% 12 yüksek risk, \% 21 çok yüksek risk seviyesi olmak üzere toplam \% 
Afet ve Risk Dergisi Cilt: 2 Sayı: 2, 2019 (128-152)

Hüseyin BAYRAKTAR, Elif SAHTIYANCI, Ali KURU

33 risk seviyesine sahiptir. Kaynaşlı Anadolu Kalkınma Vakfı Ortaokulu \% 12 yüksek risk ve \% 25 çok yüksek risk seviyeleri ile toplam \% 37 risk seviyesindedir. Kaynaşlı İlkokulu ise \% 8 yüksek ve \% 29 çok yüksek risk seviyeleri ile toplam \% 37 risk seviyesindedir. Riskli seviyelerden "yüksek" ve "çok yüksek" risk seviye oranına en az sahip okul \% 33 ile Kaynașlı Anadolu Lisesidir. Diğer iki okul Kaynaşlı Anadolu Kalkınma Vakfı Ortaokulu ve Kaynaşlı İlkokulunda ise "yüksek" ve "çok yüksek" risk seviyelerinin toplamı \% 37 risk seviyesindedir.

Üç okulda yapılan risk değerlendirmesinde kullanılan kontrol listesi (anket) ve L Matris yöntemi sonucunda okulların kritik seviyelerden "çok yüksek" ve "yüksek" risk seviyeleri toplam oranları Şekil 33'de verilmiştir. Buna göre üç okulun da risk seviyeleri oranları azımsanmayacak bir durumdadır. En az risk seviyesi \% 33 ile Kaynaşlı Anadolu Lisesinde çıkmıştır. Diğer iki okul ise \% 37 ile en çok risk seviyelerine sahip okullardır. Üç okul için bir an önce çalıșmada tespit edilen kritik seviyeli risklerin tehlikeye meydan vermeden çözülmesi yoluna gidilmesi tavsiye edilmektedir. Özellikle risk seviyesinin yüksek çıktığı Kaynașlı İlkokulunda küçük yașta ana sınıfı ve ilkokul öğrencilerinin olması bu okulda yapılacak çalışmaların önemini daha da artırmaktadır. Çünkü ana sınıfı ve ilkokul çocukları diğer ortaokul ve lise öğrencileri kadar kendilerini koruyamayacaktır.

Çalışmanın asıl amacı tespit edilen riskleri okullarımızın farkına varması ve giderilmelerinin sağlanmasıdır. Bu sayede okullarda deprem öncesi risklere yönelik yapılacak hazırlıklar olası bir depremde öğrencileri tehlikelerden uzak tutabilecektir.

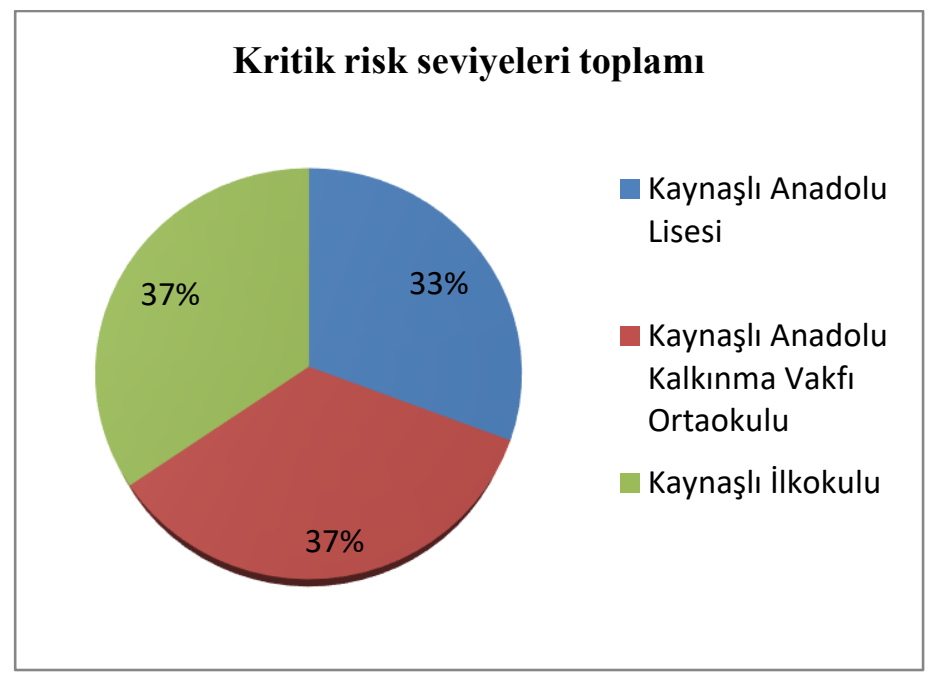

Şekil 33. Okulların kritik seviyeleri (çok yüksek ve yüksek) oranları

\section{Teșekkür}

Kaynaşlı Kaymakamlığı, İlçe Milli Eğitim Müdürlüğü, Okul Müdürleri ve görev alan öğrencilerimize verdikleri desteklerden dolayı teșekkür ederiz.

\section{KAYNAKLAR}

Acil Destek Vakfi arşivi, 1999.

AHEB, (2004). Boğaziçi Üniversitesi, Kandilli Rasathanesi ve Deprem Araştırma Enstitüsü, Afete Hazırlık Eğitim Birimi (AHEB), İstanbul, Türkiye. 
Risk Değerlendirme Matris Yöntemi Kullanarak Okullarda Deprem Kaynaklı Yapısal Olmayan Risklerin Olası Etkilerinin Belirlenmesi

Bayraktar, H. (2015). "Yapısal Olmayan Elemanların Afet Riskleri Açısından İncelenmesi". Düzce Üniversitesi, Ulusal Mühendislik Araștırmaları Sempozyumu (UMAS'15), Düzce, Türkiye.

Çeliktaş, B. ve Ünlü, N. (2018). "Risk Değerlendirme Karar Matrisi Yöntemi Kullanarak Örnek Bir Risk Değerlendirme Raporunun Oluşturulması", Jass Studies-The Journal of Academic Social Science Studies, Doi number:http://dx.doi.org/10.9761/JASSS7527, Number: 65, Spring I 2018, p. 483-504.

Durukal, E., Erdik, M., Sungay, B., Türkmen, Z., Harmandar, E. (2008). "Yapısal Olmayan Deprem Risklerinin Azaltılması". Afet Zararlarının Azaltılması Temel İlkeleri. (Editörler: Mikdat Kadıŏlu ve Emin Özdamar), T.C. İçişleri Bakanlı̆̆ı JICA Türkiye Ofisi, Yayın no:2, Ankara, Türkiye.

İpek, C. Kuzucuoğlu, H. A. ve Kıstır, R. M. (2015). "Yapısal Olmayan Sistemlerin Deprem Etkileri Açısından Değerlendirilmesi". Mehmet Akif Ersoy Üniversitesi, Uluslar arası Burdur Deprem ve Çevre Sempozyumu, Burdur, Türkiye.

Kaynaşlı Kriz Yönetim Merkezi arşivi (1999-2001 arası kayıtlı bilgiler)

Koltan, A. vd. (2010). "Risk Değerlendirmede Kullanılan L Tipi Karar Matrisi Yönteminin İşçi Sağlığı Uygunluğunun Değerlendirilmesi”, Türk Tabipler Birliği Mesleki Sağlık ve Güvenlik Dergisi, 38-43.

Özkılıç, Ö. (2005). İş Sağlığı ve Güvenliği, Yönetim Sistemleri ve Risk Değerlendirme Metodolojileri, Türkiye İşveren Sendikaları Konfederasyonu, s. 113-114, Ankara.

Özmen, B. (2000). Düzce-Bolu Bölgesi'nin Jeolojisi, Diri Fayları ve Hasar Yapan Depremleri s: 1-14, 12 Kasım 1999 Düzce Depremi Raporu (Editör: Bülent Özmen ve Günruh Bağcı), Bayındırlık ve İskan Bakanlığı Afet İşleri Genel Müdürlüğü, Deprem Araştırma Dairesi, Ankara, Türkiye.

Soykan, 0. (2018). Risk assessment in industrial fishing vessels by L type matrix method and its usability. Ege Journal of Fisheries and Aquatic Sciences, 35(2), 207-217. DOI:10.12714/egejfas.2018.35.2.15

Tantoğlu, G. (2016). "Balıkçı gemilerinde yapılan çalışmaların iş sağlığı ve güvenliği yönünden değerlendirilmesi”. T.C. Çalışma ve Sosyal Güvenlik Bakanlığı İş Sağlığı ve Güvenliğgi Genel Müdürlüğü İş sağlığı ve güvenliği uzmanlık tezi, Ankara.

T.C. Başbakanlık AFAD, Açılamalı Afet Terimleri Sözlüğü, (2014).

Ulusoy, R. (2000). 1999'da 2. Deprem Notları ve 2. Deprem Dersleri, Hacettepe Üniversitesi, Jeoloji Mühendisliği Bölümü, Ankara, Türkiye.

URL 1, Kaynaşlı İlçe Milli Eğitim Müdürlüğü sayfasından ulaşılabilir.

http://kaynasliilkokulu.meb.k12.tr/meb iys dosyalar/81/07/735220/icerikler/tarih 2668048.html (Son erişim tarihi: 05.06.2019)

URL 2, "MIL-STD-882D, 2000) Department of Defense Standard Practice For System Safety. https://www.system-safety.org/Documents/MIL-STD-882D.pdf (Son erişim tarihi: 14.06.2019)

URL3, “MIL-STD-882E, 2012) Department of Defense Standard Practice For System Safety. https://www.system-safety.org/Documents/MIL-STD-882E.pdf (Son erişim tarihi: 14.06.2019) 